NBER WORKING PAPER SERIES

\title{
ENDING "TOO BIG TO FAIL": GOVERNMENT PROMISES VS. INVESTOR PERCEPTIONS
}

Todd A. Gormley

Simon Johnson

Changyong Rhee

Working Paper 17518

http://www.nber.org/papers/w17518

\author{
NATIONAL BUREAU OF ECONOMIC RESEARCH \\ 1050 Massachusetts Avenue \\ Cambridge, MA 02138 \\ October 2011
}

We are grateful to Bruno Biais, Olivier Blanchard, Hülya Eraslan, Mike Faulkender, Radha Gopalan, Marco Pagano, Ernst-Ludwig von Thadden, Vikrant Vig, and participants at the CEPR European Summer Symposium in Financial Markets, the Olin Business School - Washington University in St. Louis Finance luncheon, M.I.T. Development \& Finance lunches, and the World Bank Finance Research Group Seminar for their many useful comments. All remaining errors and omissions are our own. The views expressed herein are those of the authors and do not necessarily reflect the views of the National Bureau of Economic Research.

NBER working papers are circulated for discussion and comment purposes. They have not been peerreviewed or been subject to the review by the NBER Board of Directors that accompanies official NBER publications.

(C) 2011 by Todd A. Gormley, Simon Johnson, and Changyong Rhee. All rights reserved. Short sections of text, not to exceed two paragraphs, may be quoted without explicit permission provided that full credit, including $\odot$ notice, is given to the source. 
Ending "Too Big To Fail": Government Promises vs. Investor Perceptions

Todd A. Gormley, Simon Johnson, and Changyong Rhee

NBER Working Paper No. 17518

October 2011

JEL No. E44,G18,G21,G3

\title{
ABSTRACT
}

Can a government credibly promise not to bailout firms whose failure would have major negative systemic consequences? Our analysis of Korea's 1997-99 crisis, suggests an answer: No. Despite a general "no bailout" policy during the crisis, the largest Korean corporate groups (chaebol) - facing severe financial and governance problems - could still borrow heavily from households through issuing bonds at prices implying very low expected default risk. The evidence suggests "too big to fail" beliefs were not eliminated by government promises, presumably because investors believed that this policy was not time consistent. Subsequent government handling of potential and actual defaults by Daewoo and Hyundai confirmed the market view that creditors would be protected.

\author{
Todd A. Gormley \\ The Wharton School \\ University of Pennsylvania \\ 3620 Locust Walk, Suite 2400 \\ Philadelphia, PA 19104 \\ tgormley@wharton.upenn.edu \\ Simon Johnson \\ MIT Sloan School of Management \\ 100 Main Street, E52-562 \\ Cambridge, MA 02142 \\ and NBER \\ sjohnson@mit.edu
}

Changyong Rhee

Economics and Research Department

Asian Development Bank

6 ADB Avenue, Mandaluyong City

1550 Philippines

crhee@adb.org 
The global financial crisis of 2008-09 and its aftermath have highlighted the problems that occur when corporate entities are "too big to fail". 'The potential bankruptcy of some large U.S. banks and nonbank financial institutions in September-October 2008 was seen by the government as likely to damage the broader economy - consequently, these firms were provided with various forms of support that kept management in place and prevented creditor losses (Sorkin 2009). More broadly, as the crisis spread around the world, many countries put in place extraordinary measures to protect their largest financial and nonfinancial firms, including banks, insurance companies, and auto manufacturers. Presumably, these efforts further undermine the incentives for careful risk management in the future - managers are less likely to be careful if they feel that downside risks (both personal and corporate) will be covered by the state, and outside investors will provide cheaper capital to such large implicitly state-guaranteed firms. ${ }^{2}$ Governments may now promise not to provide further bailouts, but in the view of Alessandri and Haldane (2009, p.7) - from the Bank of England - such promises are unlikely to be believed: "Ex-ante, they [the authorities] may well say "never again". But the ex-post costs of crisis mean that such a statement lacks credibility. Knowing this, the rational response by market participants is to double their bets. This adds to the costs of future crises. And the larger these costs, the lower the credibility of 'never again' announcements."

In contrast, the current consensus in US official circles is that the government can commit not to bail out large firms. For example, Title II of the Dodd-Frank financial legislation (signed into law on July 21, 2010) creates a "resolution authority" that allows a regulatory agency

\footnotetext{
1 "Too big to fail" is far from a new issue, as discussed in detail by Stern and Feldman (2004) - in the modern American context, it dates from at least the conservatorship of Continental Illinois in the 1980s. Concerns about this issue have become more intense since fall 2008.

2 The status of "too big to fail" definitely protects creditors and should enable firms to borrow more cheaply. It may or may not also generate higher expected returns for shareholders - on the one hand, the firm is less likely to go bankrupt, but on the other hand, share values can still fall to almost zero before some recovery (as was the case with US banks in 2007-09).
} 
(the Federal Deposit Insurance Corporation) to manage the effective bankruptcy of big nonbank financial institutions, i.e., run an orderly process in which creditors and shareholders incur losses (and management can be fired) but - in principle - the financial system is not jeopardized and there is no shock to the broader economy. ${ }^{3}$ If investors view this as credible, they should no longer provide cheap funding for "too big to fail" financial institutions. ${ }^{4}$

Can such a "no bailout" government policy constitute a credible commitment that solves the problem of "too big to fail"? Ex ante promises to let companies fail - and run through some form of bankruptcy - may not be optimal when the moment for a decision actually arrives. In particular, given the "systemic" nature of financial crises - with widespread perceived contagion both within and across countries - will financial markets really believe any government when it promises not to save its biggest firms?

Relevant experience in South Korea suggests an answer: No. When financial crisis broke out at the end of 1997, the banking system was threatened with collapse and the exchange rate depreciated rapidly. At this time of crisis, government policy was explicitly and emphatically not to bailout the largest Korean conglomerates (known as chaebol), which were heavily leveraged and exposed to the ensuing financial crisis. This approach was rooted in the incoming president's long-standing dislike for and opposition to the political power of large chaebol, and the authorities attempted to make the firmest and most credible commitments in this regard,

\footnotetext{
3 The Federal Deposit Insurance Corporation (FDIC) had such authority before the Dodd-Frank bill, but only over banks with insured deposits - i.e., this did not cover non-bank financial companies and, as interpreted, also was not applied to Bank Holding Companies (typically, large banks with major non-deposit taking activities) in 2008-09.

4 This was the claim made by President Obama when he signed the Dodd-Frank bill into law in July 2010, "Finally, because of this law, the American people will never again be asked to foot the bill for Wall Street's mistakes. There will be no more taxpayer-funded bailouts. Period. If a large financial institution should ever fail, this reform gives us the ability to wind it down without endangering the broader economy. And there will be new rules to make clear that no firm is somehow protected because it is "too big to fail," so that we don't have another AIG." (http://www.marketwatch.com/story/text-of-obama-remarks-on-dodd-frank-2010-07-21)
} 
including through its agreements with the International Monetary Fund. ${ }^{5}$

Despite this, the largest conglomerates ("chaebol”) were able to borrow heavily from households through issuing bonds at low interest rates in 1998 - allowing many of them to avoid immediate failure and become even bigger relative to the economy. The largest conglomerates issued disproportionately more bonds than other firms and were able to do so at rates implying much lower default risk. There is no evidence that this advantageous access to finance was due to better historic performance, stronger prospects, preferential access to state-owned banks, implicit cross-debt guarantees among group members, or better governance within the biggest firms - if anything, all objective measures suggest that the largest conglomerates were actually in worse shape (apart from their presumed implicit government backing) relative to other Korean firms. Instead, the most plausible interpretation is that investors perceived these large firms as "too big to fail".

Investors' perceptions proved largely correct. Daewoo, Korea’s third largest conglomerate, declared bankruptcy in 1999, and Hyundai, Korea's largest conglomerate, also had a de facto default in 2000. In both cases, the Korea government, fearing another economic crisis, intervened so as to effectively and largely bail out the bond investors. ${ }^{6}$

To assess the extent to which "too big to fail" beliefs contributed to the flow of bond finance towards chaebol-affiliated firms in 1998, we obtained comprehensive data on the amount and date of issuance for every publicly placed corporate bond in Korea in 1998. The dataset, which covers 1,175 bond issues, also includes the yield to maturity for each bond issue at the

\footnotetext{
5 The government's fiscal position was healthy and there was little outstanding public debt, so bailouts were feasible. But the government, backed by the IMF and the US Treasury, stated there would be no money to protect creditors, and this was enshrined in the country's Letters of Intent with the IMF in December 1997 (Johnson and Kwak, 2010, chapter 2; also endnote 17 on p.237). Section I provides more details of this shift in government policy towards bailouts. ${ }^{6} \mathrm{Oh}$ and Rhee (2002) estimate that investors recovered $95 \%$ of their initial investment in Daewoo because of these emergency measures put in place by the Korean government. See Section I below.
} 
time of issuance along with the issuing firm's credit rating at the time. Using company names, we then matched the issuance-level data to firms' financial and ownership data, as compiled by National Information Credit Evaluation (NICE). One of the largest Korean credit evaluating firms, NICE compiles and verifies firms' annual financial statements submitted to the Korea Securities Supervisory Board. In total, the NICE data covers about 9,000 firms during the 1990s. We also use the NICE financial data to track financial flows via loans, bonds, and equity to firms before and after the financial crisis. Finally, we match this data to firms' chaebol affiliation using data provided by the Korean Fair Trade Commission (KFTC).

Using these data, we confirm that the chaebol-affiliated firms did in fact enjoy disproportionate access to bond financing in 1998. Within our panel of firms, the Herfindahl index of total gross funds rose from 0.012 in the early and mid-1990s to 0.019 in 1998 and 0.016 in 1999. This increased concentration of financial flows was driven by Korea's biggest chaebols. Firms affiliated with the top five chaebols received 34\% of net finance in 1996 and 46\% in 1998. Firms affiliated with the largest five chaebol also raised much more bond financing than anyone else - firms in the largest five chaebols accounted for 53\% of net bond flows in 1998, while firms in the next twenty-five largest chaebols only accounted for $11 \%$.

However, it is harder to establish that "too big to fail" beliefs facilitated the largest chaebols access to bonds in 1998. For example, were investors willing to lend to these large chaebols because they were better run or had better projects at the time, or was it just that investors saw them as "too big to fail"? This is a tough question because post-crisis performance was likely affected by whether or not a firm could obtain external funding. Moreover, pre-crisis performance measures are not necessarily informative as a crisis of this nature dramatically changes the relative profitability of activities, so previously profitable firms may no longer be viable. 
To control for potential differences in investment opportunities among firms, we employ two complementary approaches. First, we test for differences in post-crisis access to bond financing within industries. Using industry fixed effects to control for unobserved differences in investment opportunities across industries, we test whether a chaebol-affiliated firm enjoyed better access to capital relative to other firms in the same industry. Second, we exploit an established feature of emerging markets in general and Korea in particular - specifically the finding that corporate governance matters for firm-level outcomes in emerging markets. The literature has established that firms with weaker corporate governance had less good performance in Korea before the crisis (Joh 2003), as well as more adverse stock price outcomes during the crisis (Baek, Kang, and Park 2004). A firm’s pre-crisis corporate governance thus provides a plausible alternative proxy for a firm's likely performance and default risk following the crisis. If the bond market was allocating capital on the basis of likely performance rather than "too big to fail" beliefs, we would expect that more capital should have flowed to firms with better corporate governance (i.e., stronger safeguards against "tunneling" by insiders, which hurts both outside equity investors and creditors). ${ }^{7}$

Using this strategy, we find evidence consistent with investors believing the largest Korean firms were "too big to fail" in 1998. Chaebol-affiliated firms were able to issue significantly more bonds and at better rates relative to other firms that issued bonds in the same industry. These findings are robust to controlling for numerous firm-level characteristics measured prior to the crisis. Moreover, there is no evidence to indicate that bond prices incorporated the default risk of firms; investors appeared indifferent to credit ratings or other standard measures of default risk in 1998, and bond prices at the time of issuance yield no

\footnotetext{
7 The available governance measures are for shareholder protection. But in an environment of potential pervasive tunneling by insiders, protections provided to shareholders can also help creditors - both are helped when it is harder for managers effectively to steal value (Johnson, La Porta, Lopezde-Silanes, and Shleifer 2000).
} 
evidence that investors anticipated the eventual default of some chaebols. For example, firms affiliated with Daewoo - the second largest chaebol (by some measures) that soon defaulted actually sold bonds in 1998 with a lower interest rate than did other chaebol-affiliated firms. There is also no evidence that the bond market allocated credit to firms with better corporate governance. Instead, the chaebol-affiliated firms receiving the most bond financing in 1998 (and at the best rates) actually had the worst corporate governance (and the worst implied creditor protection against various forms of tunneling).

Overall, this evidence is consistent with Korean investors believing the very largest Korean chaebol were "too big to fail" in 1998 - despite explicit attempts by the government to establish and implement a "no bailout" policy. When the entire set of firms in a chaebol group were very large relative to the economy or sufficiently important to key components of the economy, it made sense for investors to expect that the government would, one way or another, eventually and substantially ride to their rescue. It is very hard to commit not to save massive firms and their investors - because of the "systemic" implications - and investors know this. Of course, if investors believe there will be such a rescue, they will reward bigger firms with cheaper access to finance, further solidifying these firms' status as "too big to fail". The Korean evidence suggests that a government commitment - no matter how binding - to not bail out large firms is unlikely to eliminate "too big to fail" beliefs because it is not time consistent and, in a crisis, emergency measures can always be brought in to help investors.

Most of the established literature on the issue of "too big to fail" has focused on the financial sector and has been relatively informal - although nevertheless quite prescient, e.g., Stern and Feldman (2004), which anticipated many of the global issues seen in 2008-09. Drawing on experience in the 1990s, Summers (2000) summarizes best practice for policy: "It is certain that a healthy financial system cannot be built on the expectation of bailouts." Our paper 
expands the set of retrospective experiences when "too big to fail" was a relevant consideration, and suggests ways to examine the relevant data. The Korean case also strongly suggests that the more general study of "too big to fail" should not be limited to the financial sector alone.

Our evidence fits well with the idea that vested interests play an important role in financial development (Morck, Wolfenzon, and Yeung 2005) and suggests links between "too big to fail" and the broader evidence that firm-level governance and financing arrangements matter for country-level macroeconomic outcomes. The link seems to be particularly strong for crises in emerging markets where firms with weaker corporate governance are more likely to suffer stock price declines when a crisis hits (Johnson, Boone, Breach, and Friedman 2000, Mitton 2002, Lemmon and Lins 2003). ${ }^{8}$

Our analysis of Korea's bond market also relates to growing evidence regarding the importance of legal institutions for financial development (Beck, Demirgüç-Kunt, and Levine 2003) and how market-based or bank-based financial systems may independently matter for economic development and growth (Beck and Levine 2002). Our paper also builds upon existing work concerning business groups in Korea (Bae, Kang, and Kim 2002), the separation of ownership and control frequently found in these firms (Claessens, Djankov, and Lang 2000), and the readjustment of credit extended to these groups following the financial crisis (Borensztein and Lee 2002).

The remainder of the paper proceeds as follows. Section I explains the nature of South Korea's financial system through the mid-1990s. Section II explains our empirical specification, and Section III describes the data. Section IV reports our regressions. Section V offers some additional analysis of loans and equity flows, and Section VI concludes.

8 This literature builds directly on the measurement of investor protection in La Porta, Lopez-deSilanes, Shleifer and Vishny (1997 and 1998). 


\section{South Korea's Chaebols and Financial System}

In this section, we briefly describe the size of Korea's largest chaebols in relation to the economy prior to the financial crisis in 1997-98, and also the development of Korea's financial market during the crises years. We place particular emphasis on the development of Korea's corporate bond market, which provided a primary channel through which firms, particularly the largest chaebols, raised capital following the crisis in 1998.

\section{A. Korean Chaebols and Financial Markets, Pre-1998}

Chaebols - groups of Korean firms connected through complicated ownership structures - dominate the Korean economy. There were hundreds of such chaebols prior to the financial crisis in 1997, but the largest five and next largest 25 chaebols were generally considered to be in a class of their own in terms of size. The five largest chaebols prior to the crises, in terms of total assets, were Hyundai, Samsung, LG, Daewoo, and SK. These five chaebols alone had combined sales of 225 trillion Won in 1996. These sales are significant relative to the size of Korea's entire gross domestic product at the time, 448.6 trillion Won. The next largest 25 chaebols also accounted for a significant share of sales in 1996. Total sales of these 25 chaebols were 86 trillion Won in 1996.' The market share of these chaebols facilitated what many considered to be a "too big to fail" belief by investors (Krueger and Yoo 2002).

The chaebols' enormous size is partially attributed to their success as exporters, combined with subsidized credit from the government, during the 1960s, 1970s, and 1980s. From the 1960s into the 1980s, the South Korean financial system, which was dominated by state-owned banks, allocated credit at the behest of the government. These directed bank credits were provided to firms that fulfilled government priorities, particularly through developing exports.

\footnotetext{
${ }^{9}$ We calculate the sales of the largest chaebols using our NICE data, which is described in Section II. The gross domestic product is provided by the Bank of Korea and given in Appendix Table II.
} 
Korean chaebols were adept beneficiaries of this system, allowing them to capture a significant share of the economy. ${ }^{10}$

In the early 1990s, there were attempts by the government to switch towards a more market-based financial system, but almost all external financing for firms continued to flow through banks. Official aggregate flows of funds data from the Bank of Korea demonstrate this. Before 1997, total annual net financial flows to the corporate sector were around 25 percent of GDP, of which financial intermediaries provided between 45 and 60 percent. ${ }^{11}$ The largest chaebols accounted for a significant share of these bank loans. About $44 \%$ of net finance flows from financial intermediaries in 1996 went to the largest 5 chaebols in 1996. Other important sources of funds before the crisis were commercial paper (17.5\% of all funding in 1996), stocks $(10.9 \%)$, and overseas borrowing $(10.4 \%)$.

Despite its large nominal size, the corporate bond market was quite inactive prior to the crisis. Corporate bonds issued prior to 1998 were essentially disguised bank loans rather than capital market instruments as Korean banks routinely guaranteed corporate bonds and held them to the maturity. Bond investment by banks was an alternative method to extend loans to a specific company when banks could not extend loans to the company due to loan exposure regulation. By investing in bonds, banks could escape the regulation which limited loan exposure per firm as bond holdings were classified as portfolio investments, not loans. Also, as banks were mostly buy-and-hold investors, there was no need for introducing a "mark-to-market" system and there was little trading in the secondary market. As are result, the bond market did not have well-functioning credit rating agencies, primary dealer, etc. prior to the banking crisis in

\footnotetext{
${ }^{10}$ See Krueger and Yoo (2002) for more details on the history and growth of chaebols.

${ }^{11}$ For example, in 1996 total financing to the corporate sector was 118,769 billion Won. Of this, 14\% came from bank lending directly and $17.5 \%$ came from banks through their purchases of bonds. A further $13.9 \%$ came from non-bank financial intermediaries. See Appendix Table II for the complete aggregate finance data from 1990-2002.
} 
1997. The government's regulation on interest rates also hampered the development of corporate bond markets. Instead of putting a ceiling on interest rates, the government took an indirect approach. It controlled the supply of corporate bonds (new issuance of corporate bonds had to be pre-approved) to manage market interest rates.

\section{B. Chaebols, the Post-Crisis Bond Market, and Bailouts}

Following the financial crisis in 1997, Korea's financial markets, which had historically favored the largest chaebols, changed dramatically. In response to the crisis, Korea's banks dramatically curtailed their lending. Net financial flows from Korea's financial intermediaries were a negative 15.9 trillion Won in 1998, indicating net repayment of loans. Because of their high leverage, this drop in bank loans, a primary source of capital for the largest chaebols, likely posed a significant challenge for chaebol-affiliated firms. The median debt-to-equity ratio of firms affiliated with a top 5 chaebol was 3.9 in 1997, and the median debt-to-equity ratio of firms affiliated with the next largest 25 chaebols was 3.6. Firms affiliated with Hyundai had a median debt-to-equity ratio of 5.1 in 1997.

At the same time, government policy towards propping up failing banks and firms also changed. The Korean Government, backed by the IMF and the US Treasury, stated there would be no money to protect individual firms, and this was enshrined in the country's Letter of Intent with the IMF at the very end of $1997 .^{12}$ These shifts were intended to signal that no firm was "too big to fail" and that government aid would not be forthcoming for troubled firms. These shifts were substantiated the government's willingness to allow some smaller chaebols to go

12 From the December 3, 1997, letter (http://www.imf.org/external/np/loi/120397.HTM): paragraph 35, "To strengthen market discipline, bankruptcy provisions according to Korean law will be allowed to operate without government interference. No government subsidized support or tax privileges will be provided to bail out individual corporations"; paragraph 17, "All support to financial institutions, other than Bank of Korea liquidity credits, will be recorded transparently in the fiscal accounts"; and the tight fiscal policy laid out in paragraphs 13 and 14. These commitments were reinforced in a second Letter of Intent on December 24, 1997. 
bankrupt in 1998. Hanil, the $27^{\text {th }}$ largest chaebol in 1997, entered bankruptcy in the second half of 1998. New Core and Geopyung, ranked $27^{\text {th }}$ and $28^{\text {th }}$ in size in 1998, also subsequently went bankrupt.

Despite their high leverage and a supposed unwillingness of the government to bailout failing firms, the chaebol-affiliated firms obtained new financing in 1998 rather easily. This was accomplished by their ability to raise significant amounts of capital through bond issues as part of an overall surge in Korea's bond market at the time. The monthly average amount of corporate bonds issued was less than 3 trillion won prior to the crisis. But, the monthly average increased to 7 trillion won in the second half of 1998, and for all of 1998, the Bank of Korea reports net bond financing was 45.9 trillion won. ${ }^{13}$ Moreover, the net finance flows from bonds in 1998 roughly equaled the net flows of financial intermediaries before the crisis. Net bond flows were 9.5 percent of GDP in 1998, whereas net flows of 'indirect finance' (i.e., banks) were about 9 percent of GDP from 1990-1997. The dramatic switch from bank-based finance to issuing bonds is shown in Figure 1, which shows the main net financial flows to the Korean corporate sector during the 1990 s as reported by the Bank of Korea. ${ }^{14}$

While the government's decision to no longer control the supply of corporate bonds was a contributing factor in the bond market's sudden development, the primary driver was a drawing down of bank deposits by households and the reinvestment of these savings in corporate bonds. Anecdotal evidence suggests that households moved their savings to corporate bonds for two

\footnotetext{
13 Using an average exchange rate of 1400 won per dollar in 1998 , this is about $\$ 32.8$ billion.

${ }_{14}$ The type of corporate bond issued also changed drastically with the crisis as guaranteed corporate bonds immediately disappeared from the market. Due to new restrictions put in place by the government after the crisis, banks and other institutional investors' ability to provide a financial guarantee to bond issuers was severely curtailed, and almost all corporate bonds issued after the crisis were non-guaranteed bonds.
} 
main reasons. ${ }^{15}$ First, there was increased uncertainty about which banks would survive the government's financial restructuring policy, whereas individuals still perceived bonds issued by chaebol-affiliated firms to be safe investments irrespective of government commitments to not bail out these firms. Second, banks could not compete with the higher interest rates offered by corporate bonds. In January 1998, the three year bank deposit rate was 17\% whereas the three year corporate bond yield (AA rating) was 24\%. The introduction of asset-backed securities and the securitization of bad bank loans also helped diversify the products available to investors and deepen their demand for bonds in 1998.

The dramatic growth of the bond market slowed after the government placed a limit on the amount of bonds that chaebol-affiliated firms could issue on October 28, 1998. This limit was implemented out of concerns that large chaebols were accumulating large amounts of debt that they would not be able to repay. These concerns were justified in July 1999 when the Daewoo group, the third largest chaebol in Korea at the time and one of the largest issuers of bonds in 1998, declared bankruptcy.

Immediately after the Daewoo bankruptcy, the amount of corporate bonds issued was almost negligible, as investors became very sensitive to corporate credit risk and the possibility that the largest chaebols were not "too big to fail". The average monthly issuance of bonds for the first half of 1999 was 2.9 trillion Won, and the total amount of bonds issued in July and August was 2.4 and 2.5 trillion Won respectively. In September 1999, however, corporate bonds issued fell to 162 billion Won, and only averaged 680 billion Won for the remainder of 1999. Total monthly bonds issued did not again exceed two trillion Won until February 2001.

Despite the Korean Government's commitment to not bail out firms, lenders to the largest chaebols were protected against losses to a large degree in 1999 and 2000 by government

15 This anecdotal evidence is based on discussions with leading Korean bond experts. Detailed data on household savings and the purchasers of corporate bonds in Korea is not available. 
action. After Daewoo’s bankruptcy, the Korea Asset Management Company (KAMCO), set up with public funds, purchased Daewoo's non-performing loans and debts, which were estimated at more than 57 billion US dollars. Oh and Rhee (2002) estimate that investors made back 95\% of their initial investment in Daewoo because of these emergency measures put in place by the Korean government. Hyundai, another large issuer of debt in 1998 also had a de facto default in 2000. Unable to rollover its debt, the company was only able to avoid bankruptcy through government measures initiated to avoid another collapse similar to Daewoo. Through these measures, the Korean Development Bank purchased bonds from Hyundai and other troubled companies, thus shielding bond investors from potential losses. ${ }^{16}$

Why were chaebol-affiliated firms able to issue so many bonds? Were these financial flows to the largest firms because these firms were better run or had better projects at the time, or was it just that investors saw them as "too big to fail"? To address this question, we now turn to our empirical specification.

\section{Empirical Specification}

To analyze whether "too big to fail" perceptions among bond investors may have contributed to chaebol-affiliated firms' ability to access bonds in 1998, we need to test whether chaebol affiliation is associated with better access to bond financing after controlling for firms' investment opportunities and underlying default risk. For example, one relationship of interest is:

$$
F_{i, j, T}=\alpha+\beta \cdot P_{i, j, T}+\Gamma \cdot \text { Chaebol }_{i}+\varepsilon_{i, j, T}
$$

where $F_{i, j, T}$ is a measure of the finance obtained by firm $i$ in industry $j$ and period $T$, i.e., after the crisis, $P_{i, j, T}$ is a measure of the expected return on the firm's projects in $T$ (and beyond), and Chaebol $_{i}$ is an indicator for being affiliated with a large chaebol. We are interested in whether

16 See Oh and Rhee (2002) for more details of these emergency measures. 
$\Gamma>0$, which would suggest better access to capital for chaebol-affiliated firms. Likewise, another relationship of interest is:

$$
Y_{T M_{i, j, T}}=\alpha+\beta \cdot \text { Risk }_{i, j, T}+\Gamma \cdot \text { Chaebol }_{i}+\varepsilon_{i, j, T}
$$

where $Y T M_{i, j, T}$ is a measure of the yield-to-maturity offered on bond issues of firm $i$ in industry $j$

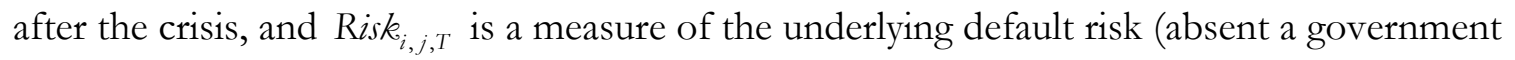
bailout) on the bonds issued by firm $i$. Now, we are interested in whether $\Gamma<0$, which would suggest investors perceived chaebol-affiliated firms as "too big to fail". The problem is that we do not have a good measure of either expected return, $P$, or default risk, Risk.

Using post-crisis performance measures to proxy for $P$ is not appealing as these are likely affected in part by access to finance, causing a potential endogeneity bias. Firms with access to the bond market following the crisis may have performed better simply because they could obtain credit when other firms could not. For example, Daewoo, which issued a large share of the bonds in 1998, was probably able to delay bankruptcy because of its ability to issue bonds. Therefore, using post-crisis performance measures would bias us towards finding a positive correlation between performance and financial access. A similar concern arises in trying to determine whether these bond issues adequately priced a firm's default risk, Risk.

Using other standard proxies for investment opportunities, such as Tobin's Q, from before the crisis to proxy for firms' expected return on investments after the crisis is also not appealing. A dramatic change in relative prices following the crisis likely shifted the set of profitable investments to new areas of the economy, and a firm's performance prior to the crisis need not be a strong predictor of its post-crisis expected returns. Using standard measures of default risk measured from before the onset of the crisis is also unappealing for the same reason.

To capture differences in investment opportunities and risk across firms, we instead rely 
on industry fixed effects. Adding industry fixed effects to the above specifications will help control for unobserved investment opportunities and risk attributes at the industry level and ensure that we are only estimating differences in post-crisis access to bond financing within industries -- i.e., are chaebol-affiliated firms able to borrow more and at better terms than other firms in the same industry?

An additional and attractive proxy for the potential risk and return of a firm's investments following the crisis is a firm's corporate governance structure prior to the crisis. Recent corporate governance literature suggests that corporate governance arrangements matter for firm-level performance (Mitton 2002, Lemmon and Lins 2003, Morck, Wolfenzon, and Yeung 2005), and there is ample evidence that corporate governance mattered for performance specifically in Korea before, during, and after the crisis (Joh 2003, Baek, Kang and Park 2004, Black, Jang, and Kim 2006). Corporate governance structures also tend to be persistent, and in Korea, they do not appear affected by the financial crisis. Thus, as an additional control for investment opportunities, we will also test the robustness of our findings to including controls for firm-level governance.

Making use of these ideas, we estimate the following specification:

$$
F_{i, j, T}=\alpha+\lambda_{j}+\beta \cdot G_{i, j, T-s}+\Gamma \cdot \text { Chaebol }_{i}+Z_{i, j, T-s}^{\prime} \cdot \gamma+\varepsilon_{i, j, T}
$$

where $F_{i, j, T}$ is the finance obtained by firm $i$ in industry $j$ and period $T$, which is after the crisis; $\lambda_{j}$ are three-digit industry fixed effects, and $G_{i, j, T-s}$ is the corporate governance of firm $i$ in period $T-s$, which is before the crisis; and $Z_{i, T-s}^{\prime}$ is a vector of firm-level controls, which are all measured before the crisis to ensure they are not endogenously related to post-crisis financial flows. We estimate a similar regression for the yield-to-maturity of bonds issued in 1998.

Our main empirical specifications will rely on industry fixed effects to capture differences 
in investment opportunities and risk. Empirical specifications that also include corporate governance as an additional proxy will rely on three assumptions. First, the crisis was a surprise to all concerned, so that corporate governance and other arrangements were not designed with the crisis in mind. Second, corporate governance is to some extent persistent, i.e., cannot be quickly changed, particularly during a crisis. ${ }^{17}$ Third, building on Joh's (2003) result that firms with bad corporate governance performed worse before the crisis, we assume it would be reasonable to suppose that in early 1998 these same firms would not make good use of external funds.

\section{Data Description}

Below, we describe the construction of variables we will use in our subsequent analysis. A more detailed description of how we construct each variable can be found in Appendix Table I. Descriptive statistics of our key variables and controls are provided in Tables I and II, and pair-wise correlations of key variables are reported in Table III. As noted in our empirical strategy, all firm-level controls, including those for chaebol membership, corporate governance, and size are measured prior to the financial crisis to ensure they are not endogenously related to post-crisis bond flows and YTM, which form our main dependent variables. To that effect, we construct all of our firm-level controls from 1996 data to ensure they are not influenced by financial crisis in mid- to late-1997. All subsequent analysis are also robust to constructing our control variables from 1997 data instead.

\section{A. Chaebol Membership}

A firm's chaebol affiliation is determined using the Korean Fair Trade Commission

\footnotetext{
17 The corporate governance measures used in our later specifications are in fact highly persistent. See Section II.A.
} 
(KFTC) annual publication of the thirty largest chaebols, according to total assets. This is the standard measure used both in the literature and by practitioners in Korea. In our subsequent analysis, a firm is classified as chaebol-affiliated based on the 1996 listing of the top thirty chaebols. According to the KFTC, there are 343 firms affiliated with a top thirty chaebol in 1996. Because there is a large distinction between the largest five chaebols (Hyundai, Samsung, LG, Daewoo, and SK) and the next largest twenty-five chaebols, in terms of overall size, we also separately identify firms affiliated with a top five chaebols and those that are affiliated with the next twenty-five largest chaebols.

There was some merger activity during the period of interest, and it is not clear how exactly to treat a firm that joins or leaves a chaebol. In our base regressions and descriptive statistics, we therefore drop all firms that become a member of a top thirty chaebol during 19972000 or leave a chaebol during 1997-98. However, in our robustness checks, we add these firms to the sample and confirm that our results are robust to treating these firms as either non-chaebol or chaebol and clustering the standard errors on either pre- or post-crisis chaebol affiliation.

In our base regressions, we cluster the standard errors by chaebol to avoid overstating the findings, which might occur if financing decisions or idiosyncratic shocks occur at the group level rather than among individual firms. Our results are robust to not clustering.

\section{B. Financial Flows and Firm Characteristics}

Our measures of firm-level financial flows, i.e., bonds, loans, and equity, are derived from operating activity cash flow data reported a dataset compiled by the National Information Credit Evaluation (NICE). One of the largest Korean credit evaluating firms, NICE compiles and verifies firms' annual financial statements submitted to the Korea Securities Supervisory Board. After excluding observations on financial firms, the NICE data set contains the financial statements for approximately 6,400 non-financial firms in 1996 and 8,800 firms by 2000. 
The NICE financial dataset captures a large share of the Korean economy, and the aggregate pattern of financial flows for firms in the dataset closely mirror those of the entire Korean economy. This is shown in Figure 2, where we calculate the aggregate net equity, bond, and financial intermediary flows by year using NICE. The overall amount and changes in net financial flows reported by NICE are very similar to those reported by the Bank of Korea, as reported in Figure $1 .{ }^{18}$ Net financing from loans is almost zero in 1998, while financing from bond issues provides the primary source of capital in 1998. Equity-financing is relatively small, except in 1999.

The chaebol-affiliated firms, particularly those in a top five chaebol, appear to issue a disproportionate share of the bonds in the post-crisis years. This is seen in Table I, where we report the number of firms that report positive cash inflows from bond issuances and the average gross bond flows normalized by assets for firms from 1996-2000. Between 500 and 600 firms issue bonds each year in the three years following the crisis, but about 20 percent of the issuers are affiliated with a large chaebol even though these firms account for less than four percent of the firms in the NICE dataset. The chaebol-affiliated firms also issue far more bonds per unit of assets than non-chaebol firms. The average gross bond flows normalized by assets is around one from 1997 to 2000 for all firms, and for chaebol-affiliated firms, it is four times larger.

In 1998, the concentration of bond flows among the largest five chaebols is even starker. Average gross bond flows normalized by assets is 10.9 for firms affiliated with the five largest chaebols, compared to just 0.93 for all firms. In fact, the fifty-four firms associated with the top five chaebols - and actively issuing bonds in 1998 - accounted for 56 percent of the gross bond

\footnotetext{
${ }_{18}$ Note that the Bank of Korea construction of net bond flows used in Figure 1 does not include bonds issued overseas with foreign currency denomination, while our measurement of bond flows from the NICE data does include such bonds. Moreover, we cannot separate out commercial paper from our loans in the NICE data. Despite these differences in how the two datasets are constructed, the two series show the same general pattern.
} 
flows, though they only account for 10 percent of the firms that issue bonds in 1998. And the fifty-nine firms associated with the next twenty five largest chaebols and actively issuing bonds in 1998 accounted for $13 \%$ of gross bond flows in $1998 .^{19}$

The number of firms with cash inflows from loans or equity in 1998 is larger, but the net financial flows from loans and equity are much smaller than that of bond flows. As seen in Table I, approximately 5,000 firms have positive net financial flows from loans in 1998. But, as shown in Figures 1 and 2, the net financial flows from the loan market were negative in 1998.

Likewise, while around 1,000 firms issued equity in 1998, the aggregate volume of net equity financing did not become sizable until 1999. On aggregate, the bond market provided the primary source of capital in the year immediately following the financial crisis.

The NICE dataset also provides us a number of other key firm-level characteristics, including firm size and leverage, which will be used as controls in our regressions. The log of total assets is used to control for overall firm size since larger firms naturally borrow more in levels. Findings are also robust to using second-, third-, and fourth-order polynomials of total assets to control for size. A firm's leverage ratio, as measured by total debt divided by assets controls for a firm's level of indebtedness and exposure to risk. We also control for the amount of cash flows generated by the firm. To do this, we calculate a firm's cash flows normalized by assets, where cash flows are measured using operating cash flows plus depreciation and minus changes in accruals. To control for the volatility of a firm's cash flow, we also calculate a firm's 'cash volatility', which is the standard deviation of cash flows/assets from 1994-1996. Finally, to capture other potential risk exposures beyond leverage, we calculate the firms modified Altman-Z

\footnotetext{
${ }_{19}$ Total gross bond flows in 1998 for firms in the NICE data were 71.9 trillion Won, of which firms in top five chaebols accounted for 40.2 trillion, and firms in next twenty-five largest chaebols accounted for 9.1 trillion Won.
} 
score. $^{20}$

As expected, chaebol-affiliated firms are much larger and less profitable than non-chaebol firms prior to the crisis. This is seen in Table II, which provides descriptive statistics for both the entire sample of firms in NICE and those that issue bonds in 1998. Firms affiliated with a top 5 chaebol are $3.1 \log$ points larger in total assets than non-chaebol firms and nearly a log point larger than firms affiliated with the twenty-five largest chaebols. Overall, firms affiliated with a top 30 chaebol account for approximately 40\% of total assets and 50\% of total sales in 1996. Confirming that the top five are much larger than even the next twenty-five largest chaebols, they alone account for $25 \%$ of assets and $36 \%$ of sales. At the same time, however, firms affiliated with a top 30 chaebol are less profitable than non-chaebol firms, as captured by a lower ROA in 1996. This is also true among the subset of firms that successfully issue bonds in 1998.

\section{Corporate Governance}

To construct our pre-crisis measures of corporate governance-which again will serve as one proxy for firms' ability to invest funds successfully after the financial crisis (and the likelihood that such returns would benefit outside equity holders and creditors)—we use the NICE ownership data. This dataset lists the eight largest shareholders and their ownership stake for a subset of the firms found in the larger financial dataset provided by NICE. Ownership data is available for approximately 3,500 firms in $1996 .{ }^{21}$ We use two variables to measure corporate governance: 'control-ownership rights gap' and 'ownership concentration'. Both of these variables were used by Joh (2003) and are derived using ownership data provided by NICE.

\footnotetext{
${ }^{20}$ Following MacKie-Mason (1990), we calculate a modified-Altman z-score as 3.3*(EBIT/assets) + $1.0 *$ (sales/assets) $+1.4 *$ (retained earnings/assets) $+1.2 *$ (working capital/assets). Since we do not have stock price data, we are unable to calculate firms' ratio of market equity to book debt, and instead control for book leverage separately.

21 The pattern of total finance flows exhibited in the economy-wide data (Figure 1) and full sample of firms (Figure 2) also persists in the more restricted sample of firms with ownership data.
} 
To construct these two corporate governance measures, we first calculate the 'ownership' (cash-flow) and 'control' rights of the controlling family in each firm. Since the controlling family or founders of the firm are typically the largest shareholder, we calculate the 'ownership' rights of the controlling family by summing up all personal holdings among the largest eight shareholders reported by NICE. Thus, all institutional shareholders (financial institutions and non-financial corporations), foreign owners, government, and employee stock ownership are excluded. It is necessary to sum over all personal shareholdings since some shares are often controlled by spouses or family members of the spouse, and it is not possible to distinguish such family connections in Korea as wives do not adopt their husband's last name. The 'control' rights of these shareholders are then approximated using the total sum of ownership stakes for all eight of the largest shareholders, including the non-personal holdings excluded from the measure of 'ownership' rights. The implicit assumption is that these non-personal shareholdings among the largest shareholders are companies which are indirectly controlled by the founding family of the firm, which is typically the case in Korea. ${ }^{22}$

Our first measure of corporate governance is the 'control-ownership rights gap', which is calculated by taking the difference between the 'control' and 'ownership' rights. This measure captures the degree to which ownership and control rights are aligned within each firm. Firms with a greater spread between the control and ownership stakes of the top shareholders are more susceptible to poor management and misaligned incentives - definitely not in the interest of outside equity holders and creditors. Therefore, a larger control-ownership gap represents weaker corporate governance and should be negatively related to firm performance and positively related to default risk. In fact, this negative correlation with firm performance has been documented in a number of papers that analyze Korean firms (Joh 2003, Lemmon and Lins

\footnotetext{
22 See Joh (2003) for more details on constructing the both measures of corporate governance.
} 
2003, Baek, Kang, and Park 2004), and is also present in our dataset. As seen in Table III, where we report correlations between our key variables, the control-ownership rights gap is negatively correlated to ROA in 1996.

Our second measure of corporate governance will be the 'ownership concentration' of the firm, which is measured using the 'ownership' (cash-flow) rights of the controlling family. The inability of some institutional or smaller shareholders to exercise voting rights under Korean regulations often allows a large shareholder to maintain control with a very small ownership stake. Controlling shareholders with a larger ownership stake likely face better incentives, and thus, greater ownership concentration represents a firm with better corporate governance and should be positively related to firm performance - and to the prospect that bond holders will be repaid. Again, a number of papers have shown this positive correlation between ownership concentration and firm performance to be true in Korea (Joh 2003, Mitton 2002, Baek, Kang, and Park 2004), and we find it in our dataset as well. This is shown in Table III.

The summary statistics also support the anecdotal evidence that chaebol-affiliated firms exhibit very weak corporate governance structures. As seen in Table II, chaebol-affiliated firms have a much larger control-ownership gap and lower ownership concentration than non-chaebol firms. The control-ownership rights gap is more than twice as large for chaebol-affiliated firms in both the full sample of firms and in the smaller sample of firms that issue bonds in 1998. And, ownership concentration of chaebol-affiliated firms averages only 7-10 percent compared to 48 percent for non-chaebol firms in the full sample and 32 percent in the sample of non-chaebol firms that issue bonds in 1998.

As required for our empirical strategy, the corporate governance measures are also highly persistent over time for firms. From 1993 to 1997, both measures exhibit serial correlation coefficients of about 0.93 . Additionally, as is shown in later analysis, both measures are 
correlated with firm performance following the financial crisis. This supports our assumption that these measures provide valid proxies for firms' ability to invest funds successfully after the financial crisis.

\section{Results and Interpretation}

\section{A. Access to Bonds in 1998}

Firms affiliated with the largest chaebols received a disproportionate amount of the bond financing in 1998. This is seen in Table IV, column (i), where we regress the log of gross bond flows in 1998 onto pre-crisis measures of firm's chaebol affiliation, industry fixed effects, and other firm-level controls for size and leverage. The top five chaebol dummy is positive and highly significant. Being a member of a top five chaebol is associated with a $1.2 \mathrm{log}$ point increase in gross bond flows for a firm in 1998 relative to other firms in the same industry that also issue bonds in that year. This effect is large. One log point in the gross bond flows regression is about half a standard deviation in our sample, and the average log of gross bond flows in 1998 for all Korean firms is 16.2. The dummy for being a chaebol in the top thirty (but not the top five) is also significant, though the magnitude of the effect is about one-third of that observed for the largest five chaebols. As expected, size is a strong positive predictor of gross bond flows and leverage is a negative predictor.

The large flow of bond financing to chaebol-affiliated firms does not appear driven by these firms possessing better governance. Using corporate governance structures prior to the crisis as another proxy for firms' post-crisis ability to implement projects successfully after the crisis, we still find a very strong relationship between chaebol-affiliation and gross bond flows. Adding our control for ownership concentration in column (ii) of Table IV, we do not find any correlation between ownership concentration and bond flows in 1998. But, we do find a 
negative relationship between control-ownership rights gap and bond flows [column (iii)], which weakly suggests that firms with worse governance issued fewer bonds. Both the top five chaebol and top 6-30 chaebol indicators, however, remain positive and highly significant predictors of bond flows.

The disproportionate access to bonds for firms affiliated with the largest chaebols also strongly suggests that these financial flows were not related to firms' presumed ability to invest the funds successfully. As shown earlier, chaebol-affiliated firms typically had the weakest corporate governance structures and overall profitability prior to the crisis. As a robustness check, we also confirm that firms' pre-crisis profitability is also not positively related to post-crisis bond flows.

Other firm-level differences in risk exposure or access to cash do not seem to explain the preferential access to bond financing for chaebol-affiliated firms. In column (iv) of Table IV, we instead use pre-crisis controls for cash flows, volatility of cash flows, and bankruptcy risk, as measured by the modified Altman-Z score. Again, both chaebol indicators remain a strong positive predictor of bond flows. In unreported regressions, we also found that the results are robust to adding controls for exports/sales, foreign currency borrowings/total liabilities, cash/assets, R\&D expenses, market share, and training expenditures. And, as mentioned earlier, all findings are robust to alternative forms of clustering the standard errors.

One possibility is that is that chaebol-affiliation simply proxies for overall size. As seen in Table II, chaebol-affiliated firms are much larger than the average firm. Since larger firms are likely to issue more bonds, one must worry that our control of size, $\log$ (total assets), is insufficient to capture the importance of size. However, the results for chaebol-affiliation in Table IV are robust to adding nonlinear size controls to the estimation such as second-, third-, and fourth-order polynomial controls for total assets. The findings are also robust to restricting 
our sample to only the 500 largest firms, based on total assets in 1996, and re-estimating the equation. ${ }^{23}$

Another possibility, however, may be that investors perceive chaebol-affiliated firms to possess a larger asset base to collateralize the bonds issued by the firm. In particular, chaebolaffiliated firms may benefit from cross-debt guarantees from their affiliated firms, leading investors to view the bonds as potentially backed by the entire group's asset base, rather than just the firm's individual assets. If this were true, then controlling for an individual firm's assets alone will not be sufficient. Additionally, it is possible that investors perceive chaebol-affiliated firms to be safer investments because an entire chaebols' operations will be more diversified than that of any single firm, providing another implicit benefit of any cross-debt guarantees or crosssubsidization within the chaebol. If this is true, then controlling for an individual firm's riskiness (such as cash flow volatility or the modified Altman-Z Score) will not adequately capture investors' perception of risk.

However, new cross-debt guarantees were not allowed in the crisis, i.e., existing arrangements stayed in place, but any new debt issue (e.g., in the form of bonds) was not allowed to be cross-guaranteed within a chaebol (or in any other way). This was a condition of the IMF loan that helped stabilize the macroeconomy, and it was viewed as an important element of the overall economic policy both by the Korean government and by the U.S. Treasury. There was rigorous enforcement for the letter of this rule, which pertained to explicit cross-debt guarantees. ${ }^{24}$ Implicit cross-guarantees, which might occur through tunneling of cash among

23 These estimates are reported in Appendix Table III. Our findings are also robust to instead using to using net bond finance flows normalized by total assets as the dependent variable instead of $\log ($ Gross bond flows). These estimates are reported in Appendix Table IV.

24 See paragraph 37 in Korea's December 3, 1997, Letter of Intent to the IMF: http://www.imf.org/external/np/loi/120397.htm. In the official IMF summary of the program, the ban on new cross-guarantees (referred to as "phasing out") is in the third bullet point (see http://www.imf.org/External/np/exr/facts/asia.pdf). We have checked that this formal language 
group members, is also unlikely to explain our findings since the companies issuing bonds were often the largest in the chaebol making it unlikely that the other group members had sufficiently deep pockets to bail them out. ${ }^{25}$

To further exclude the possibility of implicit cross-debt guarantees driving our results, we re-estimate our main regression after aggregating chaebol-affiliated firms up to the group level and treating an entire chaebol as just one observation. In particular, we calculate total assets, gross bond flows, and our other controls for cash flows and bankruptcy risk at the group level. For our corporate governance measures, we use the average ownership concentration and control-ownership rights gap of the group members as the proxy for the entire group. In unreported results, we also tried using the maximum and minimum levels of governance within the group, and the subsequent results were unchanged. Because it is not possible to classify a groups' industry, we do not include industry-year fixed effects. The estimates from these aggregated regressions are reported in Table V.

The disproportionate access of chaebol-affiliated firms does not appear driven by implicit cross-debt guarantees. As seen in Table V, column (i), the five largest chaebols still receive a much larger share of bond financing in 1998 at the group level. The estimates suggest that a top 5 chaebol group received about 1.6 log point larger flow of bonds in 1998, even after controlling for the entire group's level of assets and overall leverage ratio. There is also still a large, positive relation between bond financing and affiliation with a top 6-30 chaebol, though it is no longer always statistically significant at conventional levels. Again, we find no relation between corporate governance and bond financing in 1998 [columns (ii)-(iii)]. Controlling for the overall

matched the reality on the ground through interviews with Korean government and IMF officials, as well as with people active in the Korean bond market.

25 The subsequent failure and government bailout of Daewoo in 1999 confirms that other group members did not have the ability to tunnel sufficient resources to avoid another group member's default. 
cash flows, cash volatility, and modified Altman-Z score of the group [column (iv)] also does not affect the large, positive relation between bond financing and the chaebol indicators. ${ }^{26}$

Overall, the firm-level regressions confirm the aggregate trends and suggest that bonds were issued in 1998 predominately by chaebol-affiliated firms, particularly firms affiliated with the five biggest chaebols. The results are robust to industry fixed effects and numerous controls for the overall size of these firms and the possibility that investors may have perceived the existence of cross-debt guarantees among firms within a chaebol. Moreover, there is no evidence that bond were related to our alternative measure of firm performance, corporate governance from prior to the crisis. The primary beneficiaries of bonds, firms affiliated with the largest five chaebols, on average, had very poor corporate governance structures. This evidence appears to run counter to the notion that bond investors sought out firms best able to invest funds. Instead, it suggests that "too big to fail" beliefs may have affected investors willingness to buy massive amounts of bonds from firms affiliated with chaebols.

\section{B. YTM and Default Risk}

It is possible, however, that the poor corporate governance and default risk of firms issuing bonds was instead accounted for in the return (yield to maturity) of the bonds being issued. To test this, we obtained data on the yield to maturity (Y'TM) for every publicly placed corporate bond in Korea along with the amount and issue date of each bond issuance. In total, there were 1,175 public bond issues in 1998. Using company names, we match the issuancelevel data to a firm's financial and chaebol-affiliation data used in the previous regressions. After

\footnotetext{
26 'The chaebols' ownership of some key investment trust companies (ITCs) also does not explain their disproportionate access to bonds. ITCs were used by many individuals and institutional investors to purchase bonds in 1998, and chaebols' ownership may have influenced the portfolio choices of these ITCs. However, fund managers in these ITCs faced institutional limits on buying bonds of their affiliates, and ITCs unaffiliated with chaebols also heavily invested in bonds issued by the chaebols.
} 
doing this and excluding financial firms, we are left with data on 737 bond issues in 1998.

Using a similar specification as before, we regress a bond's YTM at time of issuance in 1998 on industry fixed effects and firm-level characteristics measured using pre-crisis (1996) data. We are interested in seeing whether pre-crisis corporate governance or chaebol-affiliation was priced by investors purchasing bonds in 1998. This would indicate that the disproportionate amount of bonds issued by the chaebol-affiliated firms and other firms with the poor corporate governance were at least priced appropriately. To capture any aggregate monthly trend in interest rates throughout 1998, we also include monthly time dummies in the regression. These regressions are reported in Table VI.

Overall, firms affiliated with a top five chaebol actually paid a lower YTM on their bonds in 1998. On average, top 5 chaebol-affiliated bonds were issued at a YTM about 1.7 percentage points less than other firms in the same industry [Table VI, column (i)]. The negative correlation between YTM and top five chaebol affiliation holds even after controlling for firm size and leverage [column (ii)]. In unreported regressions, we also find the negative correlation is robust to controlling for firm's potential exposure to exchange rate fluctuations, as captured by exports/sales and foreign currency borrowings/total liabilities. This negative correlation indicates that investors did not perceive the bonds issued by firms affiliated with the top 5 chaebols to be risky investments. There is less evidence, however, that firms in a twenty-five next largest chaebols issued bonds at lower YTMs on average than non-chaebol firms.

The lower YTM on the bond issues of chaebol-affiliated firms is robust to including our alternative proxy for default risk - a firm's pre-crisis corporate governance. Neither measure of corporate governance is significantly related to YTM in 1998, suggesting that corporate governance was not priced by investors, and a top 5 chaebol affiliation is still strongly and negatively related to Y'TM [Table VI, columns (iii)-(iv)]. Moreover, the fact that top 5 chaebol- 
affiliated firms were able to issue bonds at a lower Y'TM than the average firm, despite that chaebol-affiliated firms typically had the worst governance and profitability prior to the crisis, further suggests that investors willingness to hold these bonds was not related to firms' ability to invest the funds successfully.

Chaebol-affiliated firms ability to issue bonds at a lower YTM also does not appear to be related to the amount or maturity of the bonds being issued by these firms. There was very little variation in the maturity of the bonds in 1998; about two-thirds of the bonds were issued with a standard 3-year maturity, and nearly all of the rest had a one- or two-year maturity. And adding controls for the size of issue also does not affect our findings [Table VII, column (i)].

One possibility, however, is that chaebol-affiliated firms were less likely to default for other reasons not captured by size, leverage, or greater ability to invest funds successfully (as measured by industry fixed effects and pre-crisis corporate governance), issuance size, or maturity. To test for this possibility, we next added a control for a firms' overall credit rating at the time of the bond issuance.

To control for credit ratings, we obtained the history of credit ratings reported by three of Korea’s largest credit rating agencies: NICE, Korea Investors Service (KIS), and Korea Ratings Corporation (KR). Following the financial crises, each firm making a public issue of bonds was required to obtain a credit rating from two credit agencies. We then match these credit ratings to the bond issuance data using company names and transform each rating into a numerical value. For example, an AAA credit rating is assigned a score of twenty-six, whereas a credit score of AAA- is assigned a score of twenty-five, and so on. If the two agencies reporting a credit rating for the firm differ in their rating, we take the average of the two ratings. Of the 737 bond issues that we have YTM and firm-level data, we are able to match credit ratings for 506 of the bond issues. 
Surprisingly, there is no evidence to indicate that a bond's YTM was related to a firm's credit rating [Table VII, Column (ii)]. While the coefficient is negative, the estimate is not statistically significant. Chaebol affiliation remains a strong, negative predictor of YTM. This indicates that chaebol-affiliated firms' lower YTM is not driven by a better credit rating and that chaebol-affiliated firms were able to issue bonds at a lower YTM relative to firms of similar industry, size, leverage, and credit rating.

The lack of significant, negative correlation between YTM and credit ratings may partially be explained the relative newness of the bond market. Credit agencies may simply have been illequipped to assess accurately firms' likelihood of defaulting on their bonds, and investors were correct to ignore these credit ratings. There is evidence to suggest this may have been the case. In 1998, there is actually a positive, statistically significant correlation between credit ratings and whether the bond eventually defaulted. In other words, bonds issued in 1998 that eventually defaulted were given a better credit rating on average. Of course, these poor credit ratings could also reflect a "too big to fail" belief on the behalf of the individuals constructing these credit ratings.

Individual investors, however, do not seem to have been any better at predicting default for bonds issued in 1998. If we instead proxy for a bonds' risk using ex-post data on which firms actually declared bankruptcy between 1999-2001, we find no significant correlation between eventual default and YTM at time of issue in 1998 [Table VII, column (iii)]. In fact, in a simple regression of YTM onto an indicator for eventual default and monthly dummies in 1998, we find that YTM and eventual default were negatively related! While the estimate is not statistically significant at conventional level $(\mathrm{t}$-stat $=1.5)$, it certainly is not consistent with investors accurately pricing default risk in 1998.

These findings are striking in that they are the opposite of what one would expect to find 
in a well-functioning bond market. Not only were the largest finance flows being directed towards firms with the worst corporate governance, it would appear investors perceived these to be safe investments - in that bonds issued by chaebol-affiliated firms sold at a premium relative to other bonds. In fact, chaebol-affiliated firms that did eventually default, such as Daewoo and Hyundai, actually sold debt at a greater premium (lower interest rate) than bonds issued by firms affiliated with other chaebols, and investors appeared indifferent to credit ratings. Overall, the pricing evidence is consistent with households ex ante regarding these corporate bonds as safe investments and the large chaebol-affiliated firms as "too large to fail" in 1998.

\section{Loans, Equity, and Profitability}

\section{A. Loans, Equity, and Chaebol Affiliation}

So far, the evidence suggests that the newly developed bond market disproportionately favored chaebol-affiliated firms, and this preferential access appears consistent with a "too large to fail" perception on the behalf of Korean investors. However, it is unclear whether this preferential access to bonds was uniquely different from pre-crisis financial flows, or whether it was limited to just the development of the bond market. To look at these issues more closely, we now turn to analyze the relation between chaebol affiliation and other forms of financing before and after the crisis.

To determine whether chaebol-affiliated firms' preferential access to bonds in 1998 was different than pre-crisis financial flows, we look at relation between chaebol affiliation, corporate governance, and lending in 1996. Prior to the development of the bond market in 1998 and the equity market in 1999, loans from financial intermediaries were the primary means to raise capital in Korea. Looking at loan flows in 1996, before the onset of the financial crisis, allows us to see whether chaebol-affiliated firms also enjoyed preferential access to capital prior to the 
development of the bond market. In particular, we now use log of gross loan flows before the crisis in 1996 as the dependent variable, and our control variables are constructed using data from 1995. These estimates are reported in Table VIII.

Firms affiliated with the largest chaebols did not appear to receive a disproportionate share of the loan financing prior to the crisis relative to other firms in the same industry. The top 5 chaebol dummies are mostly negative in Table VIII, and not statistically significant from zero. There is only weak evidence that firms affiliated with the next largest 25 chaebols received a larger amount of loans relative to other firms in the same industry. This suggests that the financial flows following the crisis were even more concentrated among the chaebol-affiliated firms then financial flows before the crisis.

To determine whether chaebol-affiliated firms' preferential access to finance was limited to the bond market, we next turn to look at how chaebol affiliation is related to equity flows in 1999. Looking at equity flows in 1999 offers an interesting falsification test to our conjecture that investors wanted to invest in chaebol-affiliated firms under a perception they were "too large to fail". If this is the case, then Korean investors should have chosen to invest directly in chaebol-affiliated firms via equity in 1999 when global equity markets rose strongly and first came into fashion in Korea.

This is what we see in Table IX, where we instead use log of gross equity flows in 1999 as our dependent variable. We again see that the effect of being a chaebol-affiliated firm is highly significant and large for both the top five chaebols and top thirty (but not top five) chaebols. The magnitude of the coefficient for equity in 1999 is similar to that of bonds 1998. Moreover, now corporate governance matters, but there is no indication that the market is getting it 'right", i.e., putting more money into firms with better governance. More ownership concentration is associated with less issues of equity and a larger control-ownership gap is associated with more 
issues of equity. Moreover, firms affiliated with a chaebol, which on average had worse corporate governance structures prior to the crisis, were more likely to receive equity financing in 1999.

\section{B. Corporate Governance \& Post-crisis Profitability}

In our specifications that include governance measures, we presume firms with better pre-crisis corporate governance are more likely to make effective use of financing in the postcrisis years. Earlier evidence pertaining to Korean firms and corporate governance before and during the crisis suggest this to be true (Joh 2003, Baek, Kang and Park 2004). In Table X, we

test this directly by regressing ROA onto our chaebol dummies and ownership concentration for each post-crisis year.

In 1998, the coefficient estimate for ownership concentration is positive and significant indicating that firms with better corporate governance prior to the crisis were, in fact, more profitable on average immediately after the crisis. This is striking given our earlier estimates indicate that these firms with greater ownership concentration were no more likely to issue bonds in 1998. In unreported results, we also found a negative correlation between our second governance measure, the control-ownership rights gap, and ROA in 1998 as we might expect, though the estimate is not significant at conventional levels. In further support that firms with better pre-crisis corporate governance are more likely to make effective use of financing in the post-crisis years, ownership concentration remains a strong, positive predictor of ROA in 1999 and 2000 as well.

The top five chaebol dummy is also positively related to ROA in 1998, but it is important to emphasize that this need not imply that the chaebol-affiliated firms were better able to invest funds after the crises than other firms. As noted earlier in the discussion of our empirical strategy, post-crisis performance measures after the crisis are likely affected by access to finance. Firms with access to the bond market following the crisis may have performed better simply 
because they could obtain credit when other firms could not. In fact, the strong performance of firms affiliated with the top five chaebols in 1998 likely reflects their preferential access to bonds in that, ex-post, we know that these firms were actually more likely to go bankrupt in later years. Additionally, we can see that affiliation with a top five chaebol is not positively related to ROA in 1999 or 2000. This again highlights the importance of our empirical strategy to use industry fixed effects and pre-crisis measures of corporate governance to proxy for firms' post-crisis ability to invest funds successfully.

\section{Conclusion}

Our evidence suggests that Korean households were willing to forgo demand deposits and buy corporate bonds during the Korean banking crisis of 1997-98 because they regarded the largest chaebols as "too big to fail". There is no evidence that the bond market allocated credit to firms more likely to make better use of the funds, and there is also no evidence that default risk was appropriately priced. Chaebol-affiliated firms issued larger amounts of bonds relative to other firms in the same industry. Moreover, the large chaebol-affiliated firms receiving the most bond financing in 1998 actually had the worst corporate governance prior to crisis, indicating they would be least able to invest the funds successfully. These chaebol-affiliated firms were also able to issue bonds with a lower yield-to-maturity relative to that of other firms, and there is no evidence that corporate governance or other standard measures of default risk were priced by bond investors. In fact, firms affiliated with Daewoo, a huge chaebol that did eventually default, actually sold bonds in 1998 at a higher premium (i.e., lower interest rate) than firms affiliated with other chaebols.

These "too big to fail" beliefs persisted despite serious efforts of the Korean Government to credibly commit to not bailing out these firms. In retrospect, the market beliefs 
were correct. When some of the largest chaebols were unable to meet their debt obligations in 1999 and 2000, the Korean Government undertook a large-scale intervention to protect creditors from losses - taking the view that this was necessary in order to prevent another financial crisis. As a result, the bond investors that had invested in these chaebols largely recouped their investments. The Korean experience suggests that governments may have great difficulty convincing investors that no firm is "too big to fail", and that heavy regulation or the dismantling of these firms may be necessary.

Korea's experience also highlights the ability of large, vested interests to continue their expansion even in the face of a crisis. Funding after the Korean financial crisis was more concentrated than before the crisis, despite the fact that the crisis was due in part to large chaebol firms over-expanding based on cheap credit. Smaller firms, even those with better corporate governance structures, were unable to access the new capital markets when banks stopped lending. The net effect of the crisis, therefore, was to help large firms relative to small firms. Economic power became even more concentrated as a result, further perpetuating investors' beliefs that the large firms were "too big to fail". Rather than breaking the power of chaebols, the immediate effect of the crisis - at least in terms of financial flows - was to help further the strongest pre-crisis special interests. 


\section{References}

Alessandri, Piergiorgio and Andrew Haldane (2009) "Banking on the State," BIS Review, 139, Nov.11, Bank for International Settlements. (http://www.bis.org/review/r091111e.pdf)

Bae, Kee-Hong, Jun-Koo Kang, and Jin-Mo Kim (2002) "Tunneling or Value Added? Evidence from Mergers by Korean Business Groups," Journal of Finance, 57(6), 2695-2740.

Baek, Jae-Sung, Jun-Joo Kang, and Kyung Suh Park (2004) "Corporate Governance and Firm Value: Evidence from the Korean Financial Crisis," Journal of Financial Economics, Vol. 71 (2), February, 265-313.

Beck, Thorsten, Asli Demirgüç-Kunt, and Ross Levine (2003) "Law, Endowments, and Finance," Journal of Financial Economics, 70(2), 137-181.

Beck, Thorsten and Ross Levine (2002) "Industry Growth and Capital Allocation: Does Having a Market- or Bank-based System Matter?" Journal of Financial Economics, 64(2), 147-180.

Black, Bernard S., Hasung Jang and Woochan Kim (2006), "Does Corporate Governance Predict Firms' Market Values? Evidence form Korea," Journal of Law, Economics and Organization, 22(2), October, 366-413.

Borensztein, Eduardo and Jong-Wha Lee (2002) "Financial Crisis and Credit Crunch in Korea: Evidence from Firm-Level Data," Journal of Monetary Economics, 49(4), 853-875.

Claessens, Stijn, Simeon Djankov, and Larry H. P. Lang (2000) "The Separation of Ownership and Control in East Asian Corporations," Journal of Financial Economics, 58(1), 81-112.

Joh, Sung Wook (2003), "Corporate Governance and Firm Profitability: Evidence from Korea before the Economic Crisis," Journal of Financial Economics, Volume 68, No. 2, May, 287322.

Johnson, Simon, Peter Boone, Alasdair Breach, and Eric Friedman (2000) "Corporate Governance in the Asian Financial Crisis," Journal of Financial Economics, Vol. 58 (1-2), October/November, 141-186.

Johnson, Simon and James Kwak (2010) 13 Bankers: The Wall Street Takeover and the Next Financial Meltdown, Pantheon Books, New York.

Johnson, Simon, Rafael La Porta, Florencio Lopez-de-Silanes, and Andrei Shleifer (2000) "Tunneling," American Economic Review (Papers and Proceedings), Vol.90, no.2, pp.22-27, May.

Krueger, Anne O. and Jungho Yoo (2002) "Falling Profitability, Higher Borrowing Costs, and Chaebol Finances during the Korean Crisis," Chapter 5 in Korean Crisis and Recovery, edited by David T. Coe and Se-Jik Kim, International Monetary Fund, Washington DC, and Korea Institute for International Economic Policy, Seoul, South Korea. 
La Porta, Rafael, Florencio Lopez-de-Silanes, Andrei Shleifer and Robert W. Vishny (1997) "Legal Determinants of External Finance," Journal of Finance, 52 (3), 1113-1155.

La Porta, Rafael, Florencio Lopez-de-Silanes, Andrei Shleifer and Robert W. Vishny (1998) "Law and Finance," Journal of Political Economy, 106 (6), 1113-1155.

Lemmon, Michael L. and Karl V. Lins (2003) "Ownership Structure, Corporate Governance, and Firm Value: Evidence from the East Asian Financial Crisis," Journal of Finance, Vol. 58 (4), 1445-68.

MacKie-Mason, Jeffrey K. (1990) "Do Taxes Affect Corporate Financing Decisions?” Journal of Finance, 45(5), pp. 1471-93.

Mitton, Todd (2002) "A Cross-Firm Analysis of the Impact of Corporate Governance on the East Asian Financial Crisis," Journal of Financial Economics, 64 (2), February, 215-241.

Morck, Randall, Daniel Wolfenzon, and Bernard Yeung (2005) "Corporate Governance, Economic Entrenchment, and Growth," Journal of Economic Literature, 43(3), 655-720.

Oh, Gyutaeg and Changyong Rhee (2002) "The Role of Corporate Bond Markets in Korean Financial Restructuring Process," Chapter 7 in Korean Crisis and Recovery, edited by David T. Coe and Se-Jik Kim, International Monetary Fund, Washington DC, and Korea Institute for International Economic Policy, Seoul, South Korea.

Sorkin, Andrew Ross (2009) Too Big To Fail: The Inside Story of How Wall Street and Washington Fought to Save the Financial System - and Themselves, Viking Adult, New York.

Stern, Gary H. and Ron J. Feldman (2004) Too Big To Fail: The Hazards of Bank Bailouts, Brookings Institution Press, Washington DC.

Summers, Larry (2000) "International Financial Crises: Causes, Prevention, and Cures," American Economic Review (Papers and Proceedings), 90(2), May, 1-16. (Ely Lecture to the American Economic Association annual meeting in January 2000.) 


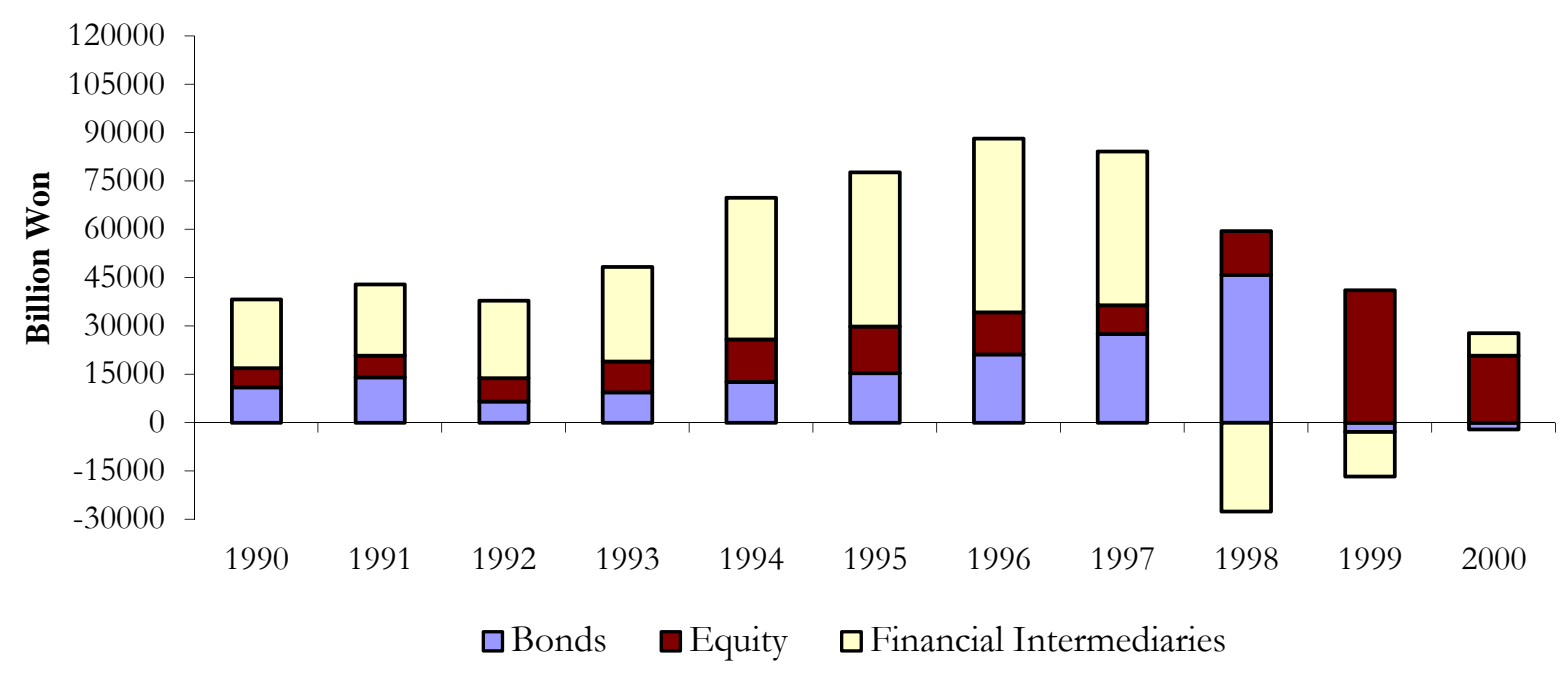

Figure 1 -- Aggregate Net Financial Flows by Year

This figure reports the aggregate corporate net financial flows for equity, bonds, and loans, by year as reported by the Bank of Korea.

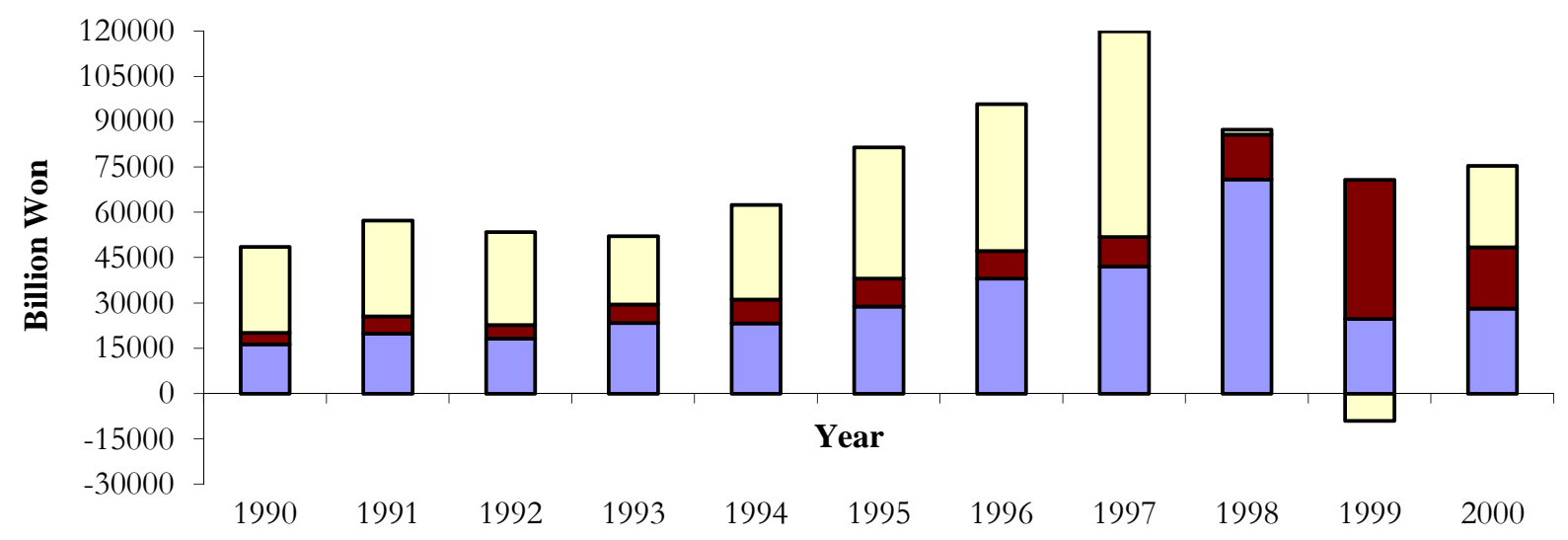

$\square$ Bonds $\square$ Equity $\quad \square$ Financial Intermediaries Plus Commercial Paper

Figure 2 -- Aggregate Net Financial Flows, As Reported by NICE This figure reports the aggregate corporate net financial flows for equity, bonds, and loans, by year as calculated from the NICE dataset. 


\section{Table I}

\section{Gross Financial Flows by Year and Chaebol Affiliation}

Financial flows are calculated using cash flow data reported under financing activities in the NICE dataset. The top 30 chaebol affiliations are determined using the 1996 KFTC listing.

\begin{tabular}{lrrrrr}
\hline & 1996 & $\mathbf{1 9 9 7}$ & $\mathbf{1 9 9 8}$ & $\mathbf{1 9 9 9}$ & $\mathbf{2 0 0 0}$ \\
\hline \hline Number of Firms with Non-zero Gross Bond Flows & 837 & 701 & 519 & 569 & 504 \\
$\quad$ Firms in a Top 5 Chaebol in 1996 & 46 & 46 & 54 & 41 & 38 \\
$\quad$ Firms in a Top 6-30 Chaebol in 1996 & 70 & 69 & 59 & 53 & 50 \\
& & & & & \\
Average Gross Bond Flows / Assets & 1.55 & 1.03 & 0.93 & 1.00 & 1.04 \\
$\quad$ Firms in a Top 5 Chaebol in 1996 & 5.3 & 5.3 & 10.9 & 4.0 & 3.8 \\
$\quad$ Firms in a Top 6-30 Chaebol in 1996 & 4.0 & 4.0 & 4.5 & 3.8 & 3.1 \\
$\quad$ & & & & & \\
Number of Firms with Other Financial Flows & & & & & \\
$\quad$ Non-zero Gross Loan Flows & 4310 & 5174 & 4784 & 5622 & 6232 \\
$\quad$ Non-zero Gross Equity Flows & 926 & 1188 & 1069 & 2133 & 2499 \\
Herfindahl Index & & & & & \\
$\quad$ Gross Bond Flows & 0.021 & 0.024 & 0.034 & 0.025 & 0.036 \\
Gross Loan Flows & 0.013 & 0.026 & 0.025 & 0.019 & 0.016 \\
Gross Equity Flows & 0.012 & 0.017 & 0.037 & 0.035 & 0.054 \\
\end{tabular}




\section{Table II}

\section{Descriptive Statistics of Firms in 1996}

All reported summary statistics are with regards to firm observations in 1996. Standard deviations are presented below the means in parentheses. Ownership concentration is the sum of personal shareholder stakes found in the NICE ownership data. The control-ownership rights gap is the difference in the total sum of shareholdings for large shareholders and personal shareholding stakes. Debt/Assets is total liabilites over total assets. Cash flows are operating cash flows plus depreciation and minus changes in accruals. Cash volatility is the standard deviation of cash flows/assets from 1994-1996. The modified altman-Z score is defined as $3.3 *$ (EBIT/assets) $+1.0 *$ (sales/assets) $+1.4 *$ (retained earnings/assets) $+1.2^{*}$ (working capital/assets). ROA is ordinary income normalized by assets.

\begin{tabular}{|c|c|c|c|c|c|c|c|c|}
\hline & \multicolumn{4}{|c|}{ All NICE Firms } & \multicolumn{4}{|c|}{ Firms That Issue Bonds in 1998} \\
\hline & $\begin{array}{l}\text { All Firms } \\
(N=6428)\end{array}$ & $\begin{array}{c}\text { Top 5 } \\
\text { Chaebols } \\
\text { Only } \\
(N=83)\end{array}$ & $\begin{array}{c}\text { Top 6-30 } \\
\text { Chaebols } \\
\text { Only } \\
(N=161)\end{array}$ & $\begin{array}{c}\text { Non- } \\
\text { Chaebol } \\
\text { Firms } \\
(N=6186)\end{array}$ & $\begin{array}{r}\text { All Firms } \\
(N=507)\end{array}$ & $\begin{array}{c}\text { Top } 5 \\
\text { Chaebols } \\
\text { Only } \\
(N=54)\end{array}$ & $\begin{array}{c}\text { Top 6-30 } \\
\text { Chaebols } \\
\text { Only } \\
(N=59)\end{array}$ & $\begin{array}{l}\text { Non- } \\
\text { Chaebol } \\
\text { Firms } \\
(N=394)\end{array}$ \\
\hline Log of Total Assets & $\begin{array}{c}16.7 \\
(1.44)\end{array}$ & $\begin{array}{c}19.7 \\
(2.10)\end{array}$ & $\begin{array}{c}18.9 \\
(1.76)\end{array}$ & $\begin{array}{c}16.6 \\
(1.33)\end{array}$ & $\begin{array}{c}18.9 \\
(1.67)\end{array}$ & $\begin{array}{c}20.9 \\
(1.48)\end{array}$ & $\begin{array}{c}20.2 \\
(1.20)\end{array}$ & $\begin{array}{c}18.5 \\
(1.46)\end{array}$ \\
\hline Debt / Assets & $\begin{array}{c}0.78 \\
(0.29)\end{array}$ & $\begin{array}{c}0.75 \\
(0.20)\end{array}$ & $\begin{array}{c}0.83 \\
(0.42)\end{array}$ & $\begin{array}{c}0.78 \\
(0.29)\end{array}$ & $\begin{array}{c}0.74 \\
(0.15)\end{array}$ & $\begin{array}{c}0.78 \\
(0.13)\end{array}$ & $\begin{array}{c}0.77 \\
(0.12)\end{array}$ & $\begin{array}{c}0.73 \\
(0.16)\end{array}$ \\
\hline Cash Flows / Assets & $\begin{array}{c}0.033 \\
(0.174)\end{array}$ & $\begin{array}{c}0.040 \\
(0.117)\end{array}$ & $\begin{array}{l}-0.007 \\
(0.210)\end{array}$ & $\begin{array}{c}0.034 \\
(0.174)\end{array}$ & $\begin{array}{c}0.044 \\
(0.100)\end{array}$ & $\begin{array}{c}0.044 \\
(0.084)\end{array}$ & $\begin{array}{c}0.026 \\
(0.072)\end{array}$ & $\begin{array}{c}0.046 \\
(0.106)\end{array}$ \\
\hline Cash Volatility [1994-1996] & $\begin{array}{c}0.116 \\
(0.122)\end{array}$ & $\begin{array}{c}0.090 \\
(0.121)\end{array}$ & $\begin{array}{c}0.112 \\
(0.175)\end{array}$ & $\begin{array}{c}0.117 \\
(0.120)\end{array}$ & $\begin{array}{c}0.067 \\
(0.053)\end{array}$ & $\begin{array}{c}0.060 \\
(0.046)\end{array}$ & $\begin{array}{c}0.061 \\
(0.041)\end{array}$ & $\begin{array}{c}0.069 \\
(0.055)\end{array}$ \\
\hline Modified Altman-Z Score & $\begin{array}{c}1.44 \\
(1.58)\end{array}$ & $\begin{array}{c}1.98 \\
(5.11)\end{array}$ & $\begin{array}{c}0.92 \\
(1.86)\end{array}$ & $\begin{array}{c}1.45 \\
(1.45)\end{array}$ & $\begin{array}{c}1.41 \\
(2.25)\end{array}$ & $\begin{array}{c}2.22 \\
(6.16)\end{array}$ & $\begin{array}{c}1.35 \\
(1.97)\end{array}$ & $\begin{array}{c}1.30 \\
(0.71)\end{array}$ \\
\hline ROA & $\begin{array}{c}0.019 \\
(0.121)\end{array}$ & $\begin{array}{c}0.011 \\
(0.108)\end{array}$ & $\begin{array}{l}-0.015 \\
(0.133)\end{array}$ & $\begin{array}{c}0.020 \\
(0.121)\end{array}$ & $\begin{array}{c}0.019 \\
(0.049)\end{array}$ & $\begin{array}{c}0.010 \\
(0.039)\end{array}$ & $\begin{array}{c}0.007 \\
(0.036)\end{array}$ & $\begin{array}{c}0.022 \\
(0.052)\end{array}$ \\
\hline Ownership Concentration ( $\%)$ & $\begin{array}{c}46.3 \\
(35.1)\end{array}$ & $\begin{array}{c}6.8 \\
(18.1)\end{array}$ & $\begin{array}{c}12.0 \\
(21.5)\end{array}$ & $\begin{array}{c}48.1 \\
(34.7)\end{array}$ & $\begin{array}{c}26.1 \\
(26.8)\end{array}$ & $\begin{array}{c}6.5 \\
(18.4)\end{array}$ & $\begin{array}{c}9.3 \\
(13.4)\end{array}$ & $\begin{array}{c}31.6 \\
(27.0)\end{array}$ \\
\hline Control-Ownership Rights Gap (\%) & $\begin{array}{c}21.2 \\
(33.5)\end{array}$ & $\begin{array}{c}45.2 \\
(34.4)\end{array}$ & $\begin{array}{c}48.2 \\
(38.0)\end{array}$ & $\begin{array}{c}19.8 \\
(32.8)\end{array}$ & $\begin{array}{c}19.5 \\
(28.7)\end{array}$ & $\begin{array}{c}38.2 \\
(32.0)\end{array}$ & $\begin{array}{c}28.2 \\
(30.1)\end{array}$ & $\begin{array}{c}15.4 \\
(26.7)\end{array}$ \\
\hline
\end{tabular}




\section{Table III}

\section{Correlations Between Key Variables}

The table reports pairwise correlations between key variables. Ownership concentration is Joh's sum of personal shareholdings using the largest eight shareholders identified by NICE. The Control-Ownership Gap is Joh's difference between the sum of all large shareholdings and the sum of only personal shareholdings using the largest eight shareholders identified by NICE. Both ownership concentration and the control-ownership rights gap are measured as of 1996 . Top 5 and Top 6-30 chaebol indicator variables are determined using the 1996 KFTC listing of the top 30 chaebols. Firms entering a top 30 chaebol from $1997-2000$ and firms that exit a chaebol from 1997-98 are dropped. 'Debt' refers to total liabilities, and ROA refers to ordinary income / assets in 1998.

\begin{tabular}{|c|c|c|c|c|c|c|c|c|}
\hline & $\begin{array}{c}\text { Log(Bond } \\
\text { Flows in } \\
\text { 1998) }\end{array}$ & $\begin{array}{c}\text { ROA in } \\
1998\end{array}$ & $\begin{array}{c}\text { Top } 5 \\
\text { Chaebol }\end{array}$ & $\begin{array}{l}\text { Top 6-30 } \\
\text { Chaebol }\end{array}$ & $\begin{array}{l}\text { Ownership } \\
\text { Conc. }\end{array}$ & $\begin{array}{c}\text { Control- } \\
\text { Ownership } \\
\text { Gap }\end{array}$ & $\begin{array}{c}\text { Log(Total } \\
\text { Assets) }\end{array}$ & $\begin{array}{l}\text { Debt / } \\
\text { Assets }\end{array}$ \\
\hline Log(Bond Flows in 1998) & 1 & & & & & & & \\
\hline ROA in 1998 & 0.120 & 1 & & & & & & \\
\hline Top 5 Chaebol in 1996 & 0.446 & -0.001 & 1 & & & & & \\
\hline Top 6-30 Chaebol in 1996 & 0.229 & -0.004 & -0.0181 & 1 & & & & \\
\hline Ownership Concentration in 1996 & -0.411 & 0.085 & -0.144 & -0.180 & 1 & & & \\
\hline Control-Ownership Rights Gap in 1996 & 0.020 & -0.013 & 0.092 & 0.150 & -0.641 & 1 & & \\
\hline Log(Total Assets) in 1996 & 0.823 & -0.001 & 0.238 & 0.244 & -0.346 & 0.087 & 1 & \\
\hline Debt / Assets in 1996 & -0.075 & -0.003 & -0.011 & 0.026 & 0.117 & -0.098 & 0.046 & 1 \\
\hline
\end{tabular}




\section{Table IV}

\section{Post-Crisis Bond Flows, Chaebol Affiliation \& Governance}

The table reports coefficients from firm-level regressions of log 1998 gross bond flows (in 1000s Won) onto 3-digit industy fixed effects and pre-crisis firm characteristics using OLS with standard errors clustered around chaebol affiliation. All RHS variables are measured with respect to 1996. Ownership concentration is Joh's sum of personal shareholdings using the largest eight shareholders identified by NICE. The Control-Ownership Gap is Joh's difference between the sum of all large shareholdings and the sum of only personal shareholdings using the largest eight shareholders identified by NICE. Top 5 and Top 6-30 chaebol indicator variables are determined using the 1996 KFTC listing of the top 30 chaebols. Firms entering a top 30 chaebol from 1997-2000 and firms that exit a chaebol from 1997-98 are dropped. 'Debt' refers to total liabilities. 'Cash flows' are operating cash flows plus depreciation and minus changes in accruals. 'Cash volatility' is the standard deviation of cash flows/assets from 1994-1996. The modified altman-Z score is defined as $3.3^{*}($ EBIT / assets $)+1.0^{*}($ sales $/$ assets $)+1.4^{*}($ retained earnings / assets) $+1.2 *$ (working capital / assets). $*=10 \%$ level, $* *=5 \%$ level, $* * *=1 \%$ level.

\begin{tabular}{|c|c|c|c|c|}
\hline \multirow[t]{2}{*}{ Dependent Variable = } & \multicolumn{4}{|c|}{ Log(Bond Flows in 1998) } \\
\hline & (i) & (ii) & (iiii) & (iv) \\
\hline Top 5 Chaebol & $\begin{array}{l}1.234^{* * *} \\
(0.275)\end{array}$ & $\begin{array}{l}1.352^{* * *} \\
(0.355)\end{array}$ & $\begin{array}{l}1.463^{* * *} \\
(0.348)\end{array}$ & $\begin{array}{l}1.303^{* * *} \\
(0.254)\end{array}$ \\
\hline Top 6-30 Chaebol & $\begin{array}{l}0.516 * * \\
(0.213)\end{array}$ & $\begin{array}{l}0.536^{*} \\
(0.289)\end{array}$ & $\begin{array}{l}0.596 * * \\
(0.295)\end{array}$ & $\begin{array}{l}0.579 \text { *** } \\
(0.211)\end{array}$ \\
\hline Log(Assets) & $\begin{array}{l}1.004 * * * \\
(0.049)\end{array}$ & $\begin{array}{l}1.136 * * * \\
(0.076)\end{array}$ & $\begin{array}{l}1.108^{* * *} \\
(0.072)\end{array}$ & $\begin{array}{l}1.027 \text { *** } \\
(0.053)\end{array}$ \\
\hline Debt / Assets & $\begin{array}{l}-1.165^{* *} \\
(0.570)\end{array}$ & $\begin{array}{l}-2.021 * * * \\
(0.699)\end{array}$ & $\begin{array}{l}-1.887 * * * \\
(0.629)\end{array}$ & $\begin{array}{c}-1.059 * \\
(0.573)\end{array}$ \\
\hline Ownership Concentration & & $\begin{array}{l}0.251 \\
(0.467)\end{array}$ & & \\
\hline Control-Ownership Difference & & & $\begin{array}{c}-0.586^{*} \\
(0.324)\end{array}$ & \\
\hline Cash Flows / Assets & & & & $\begin{array}{l}1.662^{*} \\
(1.003)\end{array}$ \\
\hline Cash Volatility & & & & $\begin{array}{l}2.442 \\
(1.959)\end{array}$ \\
\hline Modified Altman-Z Score & & & & $\begin{array}{l}-0.002 \\
(0.016)\end{array}$ \\
\hline Industry Fixed Effects & YES & YES & YES & YES \\
\hline Observations & 504 & 349 & 349 & 476 \\
\hline R-squared & 0.75 & 0.76 & 0.76 & 0.76 \\
\hline
\end{tabular}




\section{Table V}

\section{Bond Flows at Group Level}

The table reports coefficients from group-level regressions of log 1998 gross bond flows (in 1000s Won) onto precrisis firm characteristics using OLS with standard errors clustered around chaebol affiliation. For firms affiliated with a chaebol, all variables are aggregated to the chaebol-level, and the chaebol is treated as one observation. All RHS variables are measured with respect to 1996. Ownership concentration is Joh's sum of personal shareholdings using the largest eight shareholders identified by NICE. The Control-Ownership Gap is Joh's difference between the sum of all large shareholdings and the sum of only personal shareholdings using the largest eight shareholders identified by NICE. Top 5 and Top 6-30 chaebol indicator variables are determined using the 1996 KFTC listing of the top 30 chaebols. Firms entering a top 30 chaebol from 1997-2000 and firms that exit a chaebol from 1997-98 are dropped. 'Debt' refers to total liabilities. 'Cash flows' are operating cash flows plus depreciation and minus changes in accruals. 'Cash volatility' is the standard deviation of cash flows/assets from 1994-1996. The modified altman- $Z$ score is defined as $3.3 *($ EBIT / assets $)+1.0 *$ (sales / assets $)+1.4 *$ (retained earnings / assets $)+1.2 *($ working capital / assets). $*=10 \%$ level, $* *=5 \%$ level, $* * *=1 \%$ level.

\begin{tabular}{|c|c|c|c|c|}
\hline \multirow[t]{2}{*}{ Dependent Variable = } & \multicolumn{4}{|c|}{ Log(Bond Flows in 1998) } \\
\hline & (i) & (ii) & (iii) & (iv) \\
\hline Top 5 Chaebol & $\begin{array}{l}1.620^{* * *} \\
(0.272)\end{array}$ & $\begin{array}{l}1.499 * * * \\
(0.346)\end{array}$ & $\begin{array}{l}1.642^{* * *} \\
(0.360)\end{array}$ & $\begin{array}{l}1.715^{* * *} \\
(0.358)\end{array}$ \\
\hline Top 6-30 Chaebol & $\begin{array}{l}0.405 \\
(0.301)\end{array}$ & $\begin{array}{l}0.492 \\
(0.313)\end{array}$ & $\begin{array}{l}0.604 * \\
(0.318)\end{array}$ & $\begin{array}{l}0.526^{*} \\
(0.307)\end{array}$ \\
\hline Log(Assets) & $\begin{array}{l}0.988^{* * *} \\
(0.043)\end{array}$ & $\begin{array}{l}1.047 * * * \\
(0.067)\end{array}$ & $\begin{array}{l}1.048^{* * *} \\
(0.055)\end{array}$ & $\begin{array}{l}1.011^{* * *} \\
(0.049)\end{array}$ \\
\hline Debt / Assets & $\begin{array}{l}-1.772^{* * *} \\
(0.518)\end{array}$ & $\begin{array}{l}-2.787 * * * \\
(0.606)\end{array}$ & $\begin{array}{l}-2.728^{* * *} \\
(0.504)\end{array}$ & $\begin{array}{l}-2.048^{* * *} \\
(0.428)\end{array}$ \\
\hline Ownership Concentration & & $\begin{array}{l}0.011 \\
(0.485)\end{array}$ & & \\
\hline Control-Ownership Difference & & & $\begin{array}{l}-0.491 \\
(0.326)\end{array}$ & \\
\hline Cash Flows / Assets & & & & $\begin{array}{l}1.305 \\
(0.964)\end{array}$ \\
\hline Cash Volatility & & & & $\begin{array}{l}4.797 * * * \\
(1.779)\end{array}$ \\
\hline Modified Altman-Z Score & & & & $\begin{array}{l}-0.062 \\
(0.129)\end{array}$ \\
\hline Observations & 415 & 289 & 289 & 393 \\
\hline R-squared & 0.66 & 0.69 & 0.70 & 0.67 \\
\hline
\end{tabular}




\section{Table VI}

\section{Bond YTMs, Chaebol Affiliation \& Corporate Governance}

The table reports coefficients from bond-issuance level regressions of 1998 bond YTMs onto 3-digit industy fixed effects and pre-crisis firm characteristics and time (month) dummies using OLS with standard errors clustered around chaebol affiliation. Dependent variable is the YTM of bonds (in percent) at the time of issuance in 1998. All RHS variables are measured with respect to 1996 levels. Ownership concentration is Joh's sum of personal shareholdings using the largest eight shareholders identified by NICE. The Control-Ownership Gap is Joh's difference between the sum of all large shareholdings and the sum of only personal shareholdings using the largest eight shareholders identified by NICE. Top 5 and Top 6-30 chaebol indicator variables are determined using the 1996 KFTC listing of the top 30 chaebols. Firms entering a top 30 chaebol from 1997-2000 and firms that exit a chaebol from 1997-98 are dropped. 'Debt' refers to total liabilities . $*=10 \%$ level, $* *=5 \%$ level, $* * *=1 \%$ level.

\begin{tabular}{|c|c|c|c|c|}
\hline \multirow[t]{2}{*}{ Dependent Variable = } & \multicolumn{4}{|c|}{ YTM of Bond Issue } \\
\hline & (i) & (iii) & (iiii) & 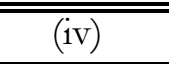 \\
\hline Top 5 Chaebol & $\begin{array}{l}-1.696 \text { *** } \\
(0.541)\end{array}$ & $\begin{array}{l}-2.137^{* * *} \\
(0.611)\end{array}$ & $\begin{array}{l}-2.280 * * * \\
(0.670)\end{array}$ & $\begin{array}{l}-2.086 \text { *** } \\
(0.725)\end{array}$ \\
\hline Top 6-30 Chaebol & $\begin{array}{l}1.320^{*} \\
(0.772)\end{array}$ & $\begin{array}{l}1.034 \\
(0.843)\end{array}$ & $\begin{array}{l}0.347 \\
(0.675)\end{array}$ & $\begin{array}{l}0.642 \\
(0.646)\end{array}$ \\
\hline Log(Total Assets) & & $\begin{array}{l}0.148 \\
(0.139)\end{array}$ & $\begin{array}{l}0.05 \\
(0.204)\end{array}$ & $\begin{array}{l}0.089 \\
(0.208)\end{array}$ \\
\hline Debt / Assets & & $\begin{array}{l}2.810^{*} \\
(1.667)\end{array}$ & $\begin{array}{l}4.409 * * \\
(1.928)\end{array}$ & $\begin{array}{l}4.458 * * \\
(1.936)\end{array}$ \\
\hline Ownership Concentration & & & $\begin{array}{l}-4.414 \\
(3.300)\end{array}$ & \\
\hline Control-Ownership Difference & & & & $\begin{array}{l}0.913 \\
(1.265)\end{array}$ \\
\hline Industry Fixed Effects & YES & YES & YES & YES \\
\hline Time (Month) FE & YES & YES & YES & YES \\
\hline Observations & 737 & 737 & 482 & 482 \\
\hline R-squared & 0.41 & 0.41 & 0.67 & 0.67 \\
\hline
\end{tabular}




\section{Table VII}

\section{Bond Y'TMs and Default Risk}

The table reports coefficients from bond-issuance level regressions of 1998 bond YTMs onto 3-digit industry fixed effects, bond \& risk characteristics, and time (month) dummies using OLS with standard errors clustered around chaebol affiliation. Dependent variable is the YTM of bonds (in percent) at the time of issuance in 1998. 'Maturity' is the number of years at time of issuance before the bond matures. 'Amount Issued' is the total amount of the bond issuance (1000s Won). 'Credit rating' captures the average credit rating of a firm's bonds where AAA $+=27, \mathrm{AAA}=26, \mathrm{AAA}-=25$, and so on to $\mathrm{D}=0$. Bankruptcy equals 1 if a firm declared bankruptcy between 1999-2001. All other RHS variables are measured with respect to 1996 levels. 'Debt' refers to total liabilities. Standard errors clustered at the chaebol level are reported in parentheses. $*=10 \%$ level, $* *=5 \%$ level, $* * *=1 \%$ level.

\begin{tabular}{|c|c|c|c|}
\hline \multirow[t]{2}{*}{ Dependent Variable = } & \multicolumn{3}{|c|}{ YTM of Bond Issue } \\
\hline & (i) & (ii) & (iiii) \\
\hline Top 5 Chaebol & $\begin{array}{c}-2.066^{* * *} \\
(0.575)\end{array}$ & $\begin{array}{c}-1.858^{*} \\
(1.077)\end{array}$ & $\begin{array}{c}-2.059 * * * \\
(0.575)\end{array}$ \\
\hline Top 6-30 Chaebol & $\begin{array}{c}1.027 \\
(0.838)\end{array}$ & $\begin{array}{c}1.14 \\
(0.955)\end{array}$ & $\begin{array}{c}1.039 \\
(0.831)\end{array}$ \\
\hline Log(Total Assets) & $\begin{array}{c}0.224 \\
(0.270)\end{array}$ & $\begin{array}{c}0.879 * * \\
(0.347)\end{array}$ & $\begin{array}{c}0.22 \\
(0.266)\end{array}$ \\
\hline Debt / Assets & $\begin{array}{l}2.784 * \\
(1.640)\end{array}$ & $\begin{array}{c}1.895 \\
(2.771)\end{array}$ & $\begin{array}{l}2.738^{*} \\
(1.608)\end{array}$ \\
\hline Log(Amount Issued) & $\begin{array}{l}-0.129 \\
(0.347)\end{array}$ & $\begin{array}{l}-0.337 \\
(0.309)\end{array}$ & $\begin{array}{l}-0.135 \\
(0.357)\end{array}$ \\
\hline Credit Rating & & $\begin{array}{l}-0.107 \\
(0.126)\end{array}$ & \\
\hline Eventual Default & & & $\begin{array}{c}0.188 \\
(0.580)\end{array}$ \\
\hline Industry Fixed Effects & YES & YES & YES \\
\hline Time (Month) Dummies & YES & YES & YES \\
\hline Observations & 737 & 506 & 737 \\
\hline R-squared & 0.41 & 0.55 & 0.41 \\
\hline
\end{tabular}




\section{Table VIII}

\section{Pre-Crisis Loan Flows, Chaebol Affiliation \& Governance}

The table reports coefficients from firm-level regressions of log 1996 gross loan flows (in 1000s of Won) onto 3-digit industry fixed effects and firm characteristics using OLS with standard errors clustered around chaebol affiliation. Ownership concentration is Joh's sum of personal shareholdings using the largest eight shareholders identified by NICE in 1996. The Control-Ownership Gap is Joh's difference between the sum of all large shareholdings and the sum of only personal shareholdings using the largest eight shareholders identified by NICE in 1996. Top 5 and Top 6-30 chaebol indicator variables are determined using the 1996 KFTC listing of the top 30 chaebols. All remaining RHS variables are measured with respect to 1995 levels. 'Debt' refers to total liabilities . 'Cash flows' are operating cash flows plus depreciation and minus changes in accruals. 'Cash volatility' is the standard deviation of cash flows/assets from 1994-1996. The modified altman-Z score is defined as $3.3^{*}($ EBIT / assets $)+1.0^{*}$ (sales / assets $)+1.4 *$ (retained earnings / assets) + $1.2 *$ (working capital / assets). $*=10 \%$ level, $* *=5 \%$ level, $* * *=1 \%$ level.

\begin{tabular}{|c|c|c|c|c|}
\hline \multirow[t]{2}{*}{ Dependent Variable = } & \multicolumn{4}{|c|}{ Log(Loan Flows in 1996) } \\
\hline & (i) & (ii) & (iii) & (iv) \\
\hline Top 5 Chaebol & $\begin{array}{l}0.083 \\
(0.290)\end{array}$ & $\begin{array}{l}-0.011 \\
(0.246)\end{array}$ & $\begin{array}{l}-0.027 \\
(0.246)\end{array}$ & $\begin{array}{l}-0.017 \\
(0.221)\end{array}$ \\
\hline Top 6-30 Chaebol & $\begin{array}{l}0.450 * * * \\
(0.163)\end{array}$ & $\begin{array}{l}0.266 \\
(0.192)\end{array}$ & $\begin{array}{l}0.251 \\
(0.193)\end{array}$ & $\begin{array}{l}0.373^{* *} \\
(0.166)\end{array}$ \\
\hline Log(Assets) & $\begin{array}{l}1.077 * * * \\
(0.024)\end{array}$ & $\begin{array}{l}1.127^{* * *} \\
(0.031)\end{array}$ & $\begin{array}{l}1.126^{* * *} \\
(0.029)\end{array}$ & $\begin{array}{l}1.106^{* * *} \\
(0.024)\end{array}$ \\
\hline Debt / Assets & $\begin{array}{l}1.181^{* * *} \\
(0.134)\end{array}$ & $\begin{array}{l}1.421 \text { *** } \\
(0.191)\end{array}$ & $\begin{array}{l}1.425^{* * *} \\
(0.191)\end{array}$ & $\begin{array}{l}1.082^{* * *} \\
(0.153)\end{array}$ \\
\hline Ownership Concentration & & $\begin{array}{l}0.011 \\
(0.093)\end{array}$ & & \\
\hline Control-Ownership Difference & & & $\begin{array}{l}0.061 \\
(0.100)\end{array}$ & \\
\hline Cash Flows / Assets & & & & $\begin{array}{l}-0.490^{* *} \\
(0.190)\end{array}$ \\
\hline Cash Volatility & & & & $\begin{array}{l}0.835^{* * *} \\
(0.280)\end{array}$ \\
\hline Modified Altman-Z Score & & & & $\begin{array}{l}-0.045^{* *} \\
(0.020)\end{array}$ \\
\hline Industry Fixed Effects & YES & YES & YES & YES \\
\hline Observations & 4246 & 2678 & 2678 & 3923 \\
\hline R-squared & 0.50 & 0.54 & 0.54 & 0.53 \\
\hline
\end{tabular}


Table IX

\section{Post-Crisis Equity Flows, Chaebol Affiliation \& Governance}

The table reports coefficients from firm-level regressions of log 1999 gross equity flows (in 1000s Won) onto 3digit industry fixed effects and pre-crisis firm characteristics using OLS with standard errors clustered around chaebol affiliation. All RHS variables are measured with respect to 1996. Ownership concentration is Joh's sum of personal shareholdings using the largest eight shareholders identified by NICE. The Control-Ownership Gap is Joh's difference between the sum of all large shareholdings and the sum of only personal shareholdings using the largest eight shareholders identified by NICE. Top 5 and Top 6-30 chaebol indicator variables are determined using the 1996 KFTC listing of the top 30 chaebols. Firms entering a top 30 chaebol from 1997-2000 and firms that exit a chaebol from 1997-98 are dropped. 'Debt' refers to total liabilities. 'Cash flows' are operating cash flows plus depreciation and minus changes in accruals. 'Cash volatility' is the standard deviation of cash flows/assets from 1994-1996. The modified altman-Z score is defined as 3.3*(EBIT / assets $)+1.0 *($ sales / assets $)+$ $1.4^{*}$ (retained earnings / assets) $+1.2^{*}$ (working capital / assets). $*=10 \%$ level, $* *=5 \%$ level, $* * *=1 \%$ level.

\begin{tabular}{|c|c|c|c|c|}
\hline \multirow[t]{2}{*}{ Dependent Variable = } & \multicolumn{4}{|c|}{ Log(Equity Flows in 1999) } \\
\hline & (i) & (ii) & (iiii) & (iv) \\
\hline Top 5 Chaebol & $\begin{array}{l}1.982^{* * *} \\
(0.415)\end{array}$ & $\begin{array}{l}1.157^{* *} \\
(0.573)\end{array}$ & $\begin{array}{l}1.096^{*} \\
(0.573)\end{array}$ & $\begin{array}{l}1.249 * * * \\
(0.441)\end{array}$ \\
\hline Top 6-30 Chaebol & $\begin{array}{l}1.439 * * * \\
(0.243)\end{array}$ & $\begin{array}{l}0.672^{* *} \\
(0.299)\end{array}$ & $\begin{array}{l}0.667^{* *} \\
(0.293)\end{array}$ & $\begin{array}{l}1.016^{* * *} \\
(0.250)\end{array}$ \\
\hline Log(Assets) & $\begin{array}{l}0.589 * * * \\
(0.039)\end{array}$ & $\begin{array}{l}0.842^{* * *} \\
(0.076)\end{array}$ & $\begin{array}{l}0.899 * * * \\
(0.071)\end{array}$ & $\begin{array}{l}0.818^{* * *} \\
(0.045)\end{array}$ \\
\hline Debt / Assets & $\begin{array}{l}-0.265 \\
(0.281)\end{array}$ & $\begin{array}{l}0.125 \\
(0.429)\end{array}$ & $\begin{array}{l}0.016 \\
(0.437)\end{array}$ & $\begin{array}{l}0.063 \\
(0.302)\end{array}$ \\
\hline Ownership Concentration & & $\begin{array}{l}-0.656^{* * *} \\
(0.245)\end{array}$ & & \\
\hline Control-Ownership Difference & & & $\begin{array}{l}0.647 * * \\
(0.268)\end{array}$ & \\
\hline Cash Flows / Assets & & & & $\begin{array}{l}-0.041 \\
(0.374)\end{array}$ \\
\hline Cash Volatility & & & & $\begin{array}{l}1.708^{* * *} \\
(0.473)\end{array}$ \\
\hline Modified Altman-Z Score & & & & $\begin{array}{l}-0.003 \\
(0.024)\end{array}$ \\
\hline Industry Fixed Effects & YES & YES & YES & YES \\
\hline Observations & 1237 & 569 & 569 & 955 \\
\hline R-squared & 0.58 & 0.65 & 0.65 & 0.65 \\
\hline
\end{tabular}




\section{Table X}

\section{Post-Crisis Profitability, Chaebol Affiliation \& Governance}

The table reports coefficients from firm-level regressions of post-crisis ratio net income over total assets onto 3-digit industry fixed effects and pre-crisis firm characteristics using OLS with standard errors clustered around chaebol affiliation. To ensure a consistent sample across years, only firms in a 1996-2000 balanced panel were included, and all RHS variables are measured with respect to 1996 levels. Ownership concentration is Joh's sum of personal shareholdings using the largest eight shareholders identified by NICE. Top 5 and Top 6-30 chaebol indicator variables are determined using the 1996 KFTC listing of the top 30 chaebols. Firms entering a top 30 chaebol from $1997-2000$ and firms that exit a chaebol from 1997-98 are dropped. Additional controls included in columns (ii), (iv), and (vi) include Log(Total Assets),

'Debt/Assets' , 'Cash flows/Assets', 'Cash volatility', and the modified altman-Z score. * $=10 \%$ level, ** $=5 \%$ level, $* * *=1 \%$ level.

\begin{tabular}{|c|c|c|c|c|c|c|}
\hline \multirow{2}{*}{ Dependent Variable $=$} & \multicolumn{2}{|c|}{1998 ROA } & \multicolumn{2}{|c|}{1999 ROA } & \multicolumn{2}{|c|}{2000 ROA } \\
\hline & (i) & (ii) & (iiii) & (iv) & (v) & (vi) \\
\hline Top 5 Chaebol & $\begin{array}{l}0.031 * * \\
(0.013)\end{array}$ & $\begin{array}{l}0.086^{* * *} \\
(0.018)\end{array}$ & $\begin{array}{l}-0.023 \\
(0.046)\end{array}$ & $\begin{array}{l}0.037 \\
(0.038)\end{array}$ & $\begin{array}{l}-0.292 \\
(0.342)\end{array}$ & $\begin{array}{l}-0.191 \\
(0.299)\end{array}$ \\
\hline Top 6-30 Chaebol & $\begin{array}{l}-0.01 \\
(0.017)\end{array}$ & $\begin{array}{l}0.025 \\
(0.019)\end{array}$ & $\begin{array}{l}-0.027 \\
(0.022)\end{array}$ & $\begin{array}{l}0.023 \\
(0.027)\end{array}$ & $\begin{array}{l}0.032 \\
(0.021)\end{array}$ & $\begin{array}{c}0.089 * * \\
(0.039)\end{array}$ \\
\hline Ownership Concentration & $\begin{array}{l}0.070 * * * \\
(0.013)\end{array}$ & $\begin{array}{l}0.041^{* * *} \\
(0.010)\end{array}$ & $\begin{array}{l}0.036^{* * *} \\
(0.009)\end{array}$ & $\begin{array}{l}0.016 * \\
(0.009)\end{array}$ & $\begin{array}{l}0.044^{* * *} \\
(0.014)\end{array}$ & $\begin{array}{l}0.004 \\
(0.019)\end{array}$ \\
\hline $\begin{array}{l}\text { Industry Fixed Effects } \\
\text { Additional Controls }\end{array}$ & YES & $\begin{array}{l}\text { YES } \\
\text { YES }\end{array}$ & YES & $\begin{array}{l}\text { YES } \\
\text { YES }\end{array}$ & YES & $\begin{array}{l}\text { YES } \\
\text { YES }\end{array}$ \\
\hline $\begin{array}{l}\text { Observations } \\
\text { R-squared }\end{array}$ & $\begin{array}{l}2277 \\
0.13\end{array}$ & $\begin{array}{l}2168 \\
0.20\end{array}$ & $\begin{array}{l}2277 \\
0.07\end{array}$ & $\begin{array}{l}2168 \\
0.14\end{array}$ & $\begin{array}{l}2277 \\
0.06\end{array}$ & $\begin{array}{l}2168 \\
0.10\end{array}$ \\
\hline
\end{tabular}




\section{Appendix Table I Definition and Source of Variables}

All variables except the price index and chaebol indicators are obtained from the NICE datasets. Numbers given in parentheses represent the actual NICE code for that particular variable.

\section{Financial Flow Variables}

Gross Bond Flows

Gross Equity Flows

Gross Loan Flows

Net Bond Flows

Net Equity Flows

Net Loan Flows
Constructed using the 'cash flows from financing activities' section of the NICE financial data set. Gross bond flows = "Increase in debentures payable" (_43121). All missing values were assumed to be zeros so long as at least one other financial cash flow variable was non-missing for that given firm-year observation.

Constructed using the 'cash flows from financing activities' section of the NICE financial data set. Gross equity flows = "Increase in capital stock" (_43140) + "Payment of margin for new stock offering" (_43150) + "Increase in Paid-in capital in excess of par values" (_43161). All missing values were assumed to be zeros so long as at least one other financial cash flow variable was non-missing for that given firm-year observation.

Constructed using the 'cash flows from financing activities' section of the NICE financial data set. Gross loan flows = "Increase in short-term borrowings" (_43111) + "Increase in long-term borrowings (Foreign Currency)" (_43122). All missing values were assumed to be zeros so long as at least one other financial cash flow variable was non-missing for that given firm-year observation.

Constructed using the 'cash flows from financing activities' section of the NICE financial data set. Net bond flows $=$ Gross bond flows -

"Redemption of debentures payable by purchase" (_43521). All missing values were assumed to be zeros so long as at least one other financial cash flow variable was non-missing for that given firm-year observation.

Constructed using the 'cash flows from financing activities' section of the NICE financial data set. Net equity flows $=$ Gross equity flows - "Decrease in capital stock" (_43550). All missing values were assumed to be zeros so long as at least one other financial cash flow variable was non-missing for that given firm-year observation.

Constructed using the 'cash flows from financing activities' section of the NICE financial data set. Net loan flows = Gross loan flows - "Redemption of short-term borrowings" (_43511) - "Redemption of long-term borrowings (foreign currency)" (_43522). All missing values were assumed to be zeros so long as at least one other financial cash flow variable was nonmissing for that given firm-year observation. 


\section{Appendix Table I Continued}

\section{Ownership Variables}

Control-Ownership Gap

This variable is obtained directly from Joh (2003), who creates the variable using the ownership data provided by NICE. For each firm, the NICE ownership data lists the largest eight shareholders and their direct

ownership stake (in percent) of that firm. 'Control-Ownership Rights Gap' is calculated by summing over the ownership stakes for all of the largest eight shareholders and than subtracting 'ownership concentration' (see below for construction of this variable). In all regressions, this variable is given as a fraction rather than a percent.

Ownership Concentration

This variable is obtained directly from Joh (2003), who creates the variable using the ownership data provided by NICE. For each firm, the NICE ownership data lists the largest eight shareholders and their direct ownership stake (in percent) of that firm. 'Ownership concentration' is calcuted by simply summing the ownership stakes for "personal" holdings among the top shareholders. All institutional shareholders (financial institutions and non-financial corporations), foreign owners, goverment, and employment stock ownership stakes are excluded from this calculation. In all regressions, this variable is given as a fraction rather than a percent.

\section{Chaebol Indicators}

Top 5 Chaebol Indicator

The top 5 chaebols are determined using the Korean Fair Trade Commision's (KFTC) annual publication of the largest 30 chaebols based on total assets. The Top 5 Chaebols indicator in the regressions uses the 1996 KFTC listing. For firms associated with a top 5 chaebol in 1996, the indicator equals "1", while the indicator equals zero for all other firms. The top 5 chaebols are Hyundai, Samsung, Daewoo, SK, and LG.

Top 6-30 Chaebol Indicator

The top 6-30 chaebols are determined using the Korean Fair Trade Commision's (KFTC) annual publication of the largest 30 chaebols based on total assets. The Top 6-30 Chaebols indicator in the regressions uses the 1996 KFTC listing. For firms associated with a top 6-30 chaebol in 1996, the indicator equals "1", while the indicator equals zero for all other firms. 


\section{Appendix Table I Continued}

\section{Firm Characteristics}

Cash Flows

Cash Volatility

Debt / Assets

Modified Altman-Z Score

Total Assets
Equals operating cash flows plus depreciation minus changes in non-cash accruals. This is calculated using the NICE financial dataset variables, "Operating Cash Flow" (_25000) - change in "Current Assets, excluding cash" (_11000 -_11110) + change in "Current Liabilities, excluding debt \& taxes" (_15000 -_15020 -_15110 __15070) + "depreciation" (_24880) + "amortization" (_24360). All missing values are assumed to be zeros.

Standard deviation of (cash flows/assets) from 1994-1996.

Equals the NICE financial dataset variable "Total Liabilities" (_16900) divided by "Total Assets (_14900). Missing values are left missing.

Defined as $3.3^{*}($ EBIT /assets $)+1.0^{*}$ (sales/assets $)+1.4^{*}$ (retained earnings/assets) $+1.2 *$ (working capital/assets), where the components are calculated using the NICE financial dataset variables,"Total Assets" (_14900), "EBIT" (_25000), "Total Sales" (_21000), "Retained Earnings" (_19000), and "Working Capital" (_11000__15000).

Equals the NICE financial dataset variable "Total Assets" (_14900). Missing values are left missing.

\section{Profit Variables}

Return on Assets (ROA) Calculated using the NICE financial dataset variable "Ordinary Income [or loss]" (_27000) normalized by total assets. Ordinary income is operating income (sales minus the cost of sales, selling expenses, and administrative expenses) minus interest payments plus dividends and gains on securities. Unlike net income, ordinary income excludes extraordinary gains or losses and taxes.

\section{Price Index}

The NICE financial dataset reports nominal values. These nominal values were indexed for inflation using the Consumer Price Index (CPI) issed by the Korean Central Bank. The base year is 2000. 


\section{Appendix Table II}

Korean Corporate Sector Net Finance Flows, 1990-2002

All values are given in units of one trillion Won. SOURCE: Bank of Korea

\begin{tabular}{|c|c|c|c|c|c|c|c|c|c|c|c|c|c|}
\hline & 1990 & 1991 & 1992 & 1993 & 1994 & 1995 & 1996 & 1997 & 1998 & 1999 & 2000 & 2001 & 2002 \\
\hline Total Financing & 50.8 & 58.2 & 54.9 & 65.0 & 89.0 & 100.0 & 118.8 & 118.0 & 27.7 & 51.8 & 65.8 & 50.6 & 83.3 \\
\hline Direct Financing & 21.5 & 22.1 & 21.3 & 31.9 & 32.5 & 48.1 & 56.1 & 44.1 & 49.5 & 24.8 & 17.2 & 37.7 & 20.0 \\
\hline Corporate Paper & 1.9 & -2.2 & 4.2 & 9.0 & 4.4 & 16.1 & 20.7 & 4.4 & -11.7 & -16.1 & -4.8 & 4.4 & -3.8 \\
\hline Bonds & 10.9 & 14.1 & 6.6 & 9.5 & 12.6 & 15.4 & 21.2 & 27.5 & 45.9 & -2.8 & -2.1 & 11.4 & -7.9 \\
\hline Stocks & 6.0 & 6.7 & 7.2 & 9.5 & 13.2 & 14.4 & 13.0 & 9.0 & 13.5 & 41.1 & 20.8 & 16.2 & 28.7 \\
\hline Indirect Finance & 19.5 & 24.3 & 19.9 & 20.4 & 39.7 & 31.9 & 33.2 & 43.4 & -15.9 & 2.2 & 11.7 & -0.3 & 51.1 \\
\hline Banks & 8.0 & 11.5 & 8.3 & 8.5 & 18.4 & 14.9 & 16.7 & 15.2 & 0.3 & 15.5 & 23.3 & 3.2 & 41.1 \\
\hline Non-Banks & 11.5 & 12.8 & 11.6 & 11.9 & 21.2 & 17.0 & 16.6 & 28.2 & -16.6 & -13.3 & -11.6 & -3.7 & 8.6 \\
\hline Overseas Borrowings & 3.2 & 2.4 & 3.9 & 1.0 & 5.9 & 8.4 & 12.4 & 6.6 & -9.8 & 11.6 & 16.8 & 0.6 & 2.4 \\
\hline Other & 6.5 & 9.4 & 9.7 & 11.7 & 11.0 & 11.7 & 17.1 & 24.0 & 3.8 & 13.2 & 20.0 & 12.6 & 10.8 \\
\hline Nominal GDP & 186.7 & 226.0 & 257.5 & 290.7 & 340.2 & 398.8 & 448.6 & 491.1 & 484.1 & 529.5 & 578.7 & 622.1 & 684.3 \\
\hline
\end{tabular}




\section{Appendix Table III \\ Bond Allocation for 500 Largest Firms}

The table reports coefficients from firm-level regressions of log 1998 gross bond flows (in 1000s Won) for the largest 500 firms (using total assets as of 1996) onto 3-digit industry fixed effects and pre-crisis firm characteristics using OLS with standard errors clustered around chaebol affiliation. All RHS variables are measured with respect to 1996.

Ownership concentration is Joh's sum of personal shareholdings using the largest eight shareholders identified by NICE. The Control-Ownership Gap is Joh's difference between the sum of all large shareholdings and the sum of only personal shareholdings using the largest eight shareholders identified by NICE. Top 5 and Top 6-30 chaebol indicator variables are determined using the 1996 KFTC listing of the top 30 chaebols. Firms entering a top 30 chaebol from 1997-2000 and firms that exit a chaebol from 1997-98 are dropped. 'Debt' refers to total liabilities . 'Cash flows' are operating cash flows plus depreciation and minus changes in accruals. 'Cash volatility' is the standard deviation of cash flows/assets from 1994-1996. The modified altman-Z score is defined as 3.3*(EBIT / assets) $+1.0^{*}$ (sales / assets) + $1.4^{*}$ (retained earnings / assets $)+1.2 *$ (working capital / assets). $*=10 \%$ level, $* *=5 \%$ level, $* * *=1 \%$ level.

\begin{tabular}{|c|c|c|c|c|}
\hline \multirow[t]{2}{*}{ Dependent Variable $=$} & \multicolumn{4}{|c|}{ Log(Bond Flows in 1998) } \\
\hline & (i) & (ii) & (iii) & (iv) \\
\hline Top 5 Chaebol & $\begin{array}{l}1.298^{* * *} \\
(0.281)\end{array}$ & $\begin{array}{l}1.573^{* * *} \\
(0.327)\end{array}$ & $\begin{array}{l}1.685^{* * *} \\
(0.317)\end{array}$ & $\begin{array}{l}1.285^{* * *} \\
(0.270)\end{array}$ \\
\hline Top 6-30 Chaebol & $\begin{array}{l}0.477 * \\
(0.252)\end{array}$ & $\begin{array}{l}0.485 \\
(0.316)\end{array}$ & $\begin{array}{l}0.541 * \\
(0.314)\end{array}$ & $\begin{array}{l}0.522^{* *} \\
(0.251)\end{array}$ \\
\hline Log(Assets) & $\begin{array}{l}1.064 * * * \\
(0.092)\end{array}$ & $\begin{array}{l}1.120^{* * *} \\
(0.132)\end{array}$ & $\begin{array}{l}1.070 * * * \\
(0.128)\end{array}$ & $\begin{array}{l}1.083^{* * *} \\
(0.092)\end{array}$ \\
\hline Debt / Assets & $\begin{array}{c}-1.490 * \\
(0.875)\end{array}$ & $\begin{array}{l}-1.834 \\
(1.141)\end{array}$ & $\begin{array}{l}-1.759 * \\
(1.055)\end{array}$ & $\begin{array}{l}-1.007 \\
(0.800)\end{array}$ \\
\hline Ownership Concentration & & $\begin{array}{l}0.214 \\
(0.493)\end{array}$ & & \\
\hline Control-Ownership Difference & & & $\begin{array}{l}-0.621 \\
(0.396)\end{array}$ & \\
\hline Cash Flows / Assets & & & & $\begin{array}{l}0.188 \\
(1.034)\end{array}$ \\
\hline Cash Volatility & & & & $\begin{array}{l}1.163 \\
(1.634)\end{array}$ \\
\hline Modified Altman-Z Score & & & & $\begin{array}{l}0.011 \\
(0.015)\end{array}$ \\
\hline Industry Fixed Effects & YES & YES & YES & YES \\
\hline Observations & 297 & 206 & 206 & 285 \\
\hline R-squared & 0.77 & 0.76 & 0.76 & 0.77 \\
\hline
\end{tabular}




\section{Appendix Table IV \\ Net Bond Flows in 1998, Chaebol Affliation \& Governance}

The table reports coefficients from firm-level regressions of 1998 net bond flows normalized by assets onto 3-digit industry fixed effects and pre-crisis firm characteristics using OLS with standard errors clustered around chaebol affiliation. All RHS variables are measured with respect to 1996. Ownership concentration is Joh's sum of personal shareholdings using the largest eight shareholders identified by NICE. The Control-Ownership Gap is Joh's difference between the sum of all large shareholdings and the sum of only personal shareholdings using the largest eight shareholders identified by NICE. Top 5 and Top 6-30 chaebol indicator variables are determined using the 1996 KFTC listing of the top 30 chaebols. Firms entering a top 30 chaebol from 1997-2000 and firms that exit a chaebol from 1997-98 are dropped. 'Debt' refers to total liabilities. 'Cash flows' are operating cash flows plus depreciation and minus changes in accruals. 'Cash volatility' is the standard deviation of cash flows/assets from 1994-1996. The modified altman-Z score is defined as 3.3*(EBIT / assets) $+1.0 *($ sales / assets) $+1.4 *$ (retained earnings / assets) $+1.2^{*}$ (working capital / assets). $*=10 \%$ level, $* *=5 \%$ level, $* * *=1 \%$ level.

\begin{tabular}{|c|c|c|c|c|}
\hline \multirow[t]{2}{*}{ Dependent Variable = } & \multicolumn{4}{|c|}{ (Net Bond Flows / Assets) in 1998} \\
\hline & (i) & (ii) & (iii) & (iv) \\
\hline Top 5 Chaebol & $\begin{array}{l}6.989 * * * \\
(1.691)\end{array}$ & $\begin{array}{l}7.008^{* * *} \\
(2.211)\end{array}$ & $\begin{array}{l}7.413^{* * *} \\
(2.176)\end{array}$ & $\begin{array}{l}7.197 * * * \\
(1.787)\end{array}$ \\
\hline Top 6-30 Chaebol & $\begin{array}{l}2.589 \\
(1.989)\end{array}$ & $\begin{array}{l}3.54 \\
(2.472)\end{array}$ & $\begin{array}{l}4.007 \\
(2.483)\end{array}$ & $\begin{array}{l}2.747 \\
(1.985)\end{array}$ \\
\hline Log(Assets) & $\begin{array}{l}0.299 \\
(0.350)\end{array}$ & $\begin{array}{l}0.536 \\
(0.538)\end{array}$ & $\begin{array}{l}0.706 \\
(0.457)\end{array}$ & $\begin{array}{l}0.531 \\
(0.341)\end{array}$ \\
\hline Debt / Assets & $\begin{array}{l}0.248 \\
(4.789)\end{array}$ & $\begin{array}{l}-3.938 \\
(3.715)\end{array}$ & $\begin{array}{l}-4.438 \\
(3.669)\end{array}$ & $\begin{array}{l}-0.094 \\
(4.783)\end{array}$ \\
\hline Ownership Concentration & & $\begin{array}{l}-2.33 \\
(2.394)\end{array}$ & & \\
\hline Control-Ownership Difference & & & $\begin{array}{l}-0.618 \\
(1.871)\end{array}$ & \\
\hline Cash Flows / Assets & & & & $\begin{array}{l}0.414 \\
(4.563)\end{array}$ \\
\hline Cash Volatility & & & & $\begin{array}{l}23.470 * * \\
(11.384)\end{array}$ \\
\hline Modified Altman-Z Score & & & & $\begin{array}{l}-0.271 \\
(0.167)\end{array}$ \\
\hline Industry Fixed Effects & YES & YES & YES & YES \\
\hline Observations & 504 & 349 & 349 & 476 \\
\hline R-squared & 0.24 & 0.32 & 0.32 & 0.28 \\
\hline
\end{tabular}

